\title{
An Approach to the Modeling of Lakes
}

\author{
By Charles R. O'Melia \\ University of North Carolina, Chapel Hill, N.C., USA ${ }^{1}$ ), and \\ Swiss Federal Institute of Technology (ETH) Zürich, Switzerland ${ }^{2}$ )
}

Models for predicting water quality reflect the physical, chemical and biological characteristics of the particular body of water under consideration. Morphology and nutrient loading, for example, have received considerable attention in the modeling of lakes. Water quality models also depend upon the objectives of the modeling study. Just as a single map cannot represent the complete geography of a region, so a single model cannot answer all questions about a natural aquatic system. Finally, water quality models depend upon the background and experience of the investigators. Given the same objectives, an aquatic biologist and an environmental engineer will most probably construct different models for the same aquatic system.

In this paper an approach to the development of predictive models for water quality in lakes is presented. This approach is intended to be somewhat general. Nevertheless, attention is directed primarily towards lake depth and nutrient loading in order to illustrate the approach in physical terms and also to provide some opportunity for comparison with existing work. The approach is biased by the background and experience of the writer; it includes physical and chemical phenomena to a greater extent than biological interactions.

\section{Comparison of stream and lake models}

Some interesting and useful comparisons in the evolution of stream and lake models are presented in Table 1. The development of stream models presented therein follows an environmental engineering (Streeter-Phelps-O'Connor) approach. Models for lakes are based primarily on the work of VollenweIder [21, 22].

Some difficulties are encountered in stream modeling when one tries to express 'polluted' and 'unpolluted' in numerical terms. The quantitative application of these terms can depend upon the use to which the water is put and upon the inputs to the system. Attention here is directed towards BOD and dissolved oxygen in streams; it is not implied that these are sufficient criteria for a complete description of stream quality. Nevertheless, models for oxygen and BOD in streams also provide a basis for the characterization of the effects of some other pollutants.

1) Professor of Environmental Science and Iingineering.

2) Visiting Professor at EAWAG (Institute for Water Resources, and Water Pollution Control) at ETH. 
Table 1. Comparisons in the development of stream and lake models.

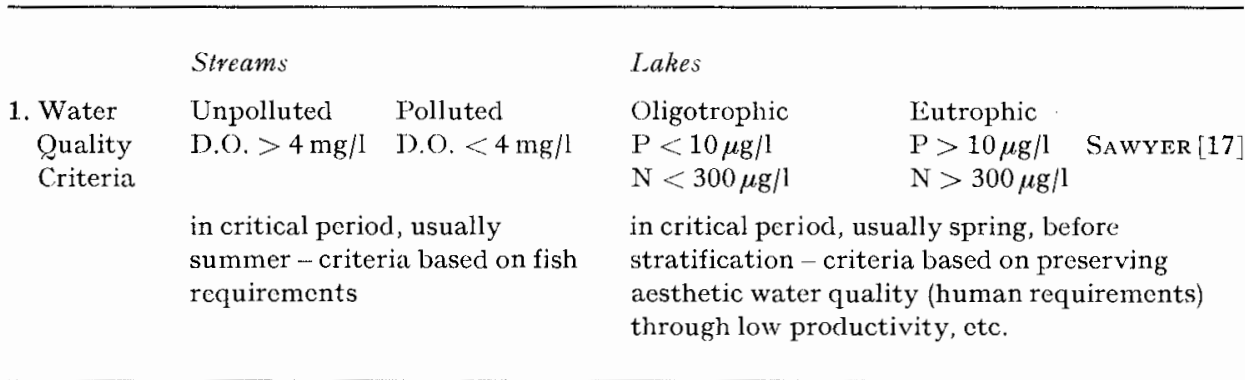

\section{Pollutant Loading \\ a) $4 \mathrm{cfs} / 1,000$ people $\left(1 \mathrm{~m}^{3} / \mathrm{s} / 100\right.$ people)}

b) consider stream characteristics (sluggish, average, rapid)

$\begin{array}{cc}\text { Depth } & \text { Allowable Ploading } \\ 5 \mathrm{ml} & 0.07 \mathrm{~g} / \mathrm{m}^{2} \cdot \text { year } \\ 200 \mathrm{~m} & 0.60 \mathrm{~g} / \mathrm{m}^{2} \cdot \text { year } \\ \text { (1rom VolLENWEIDER }[21], \text { p. } 77 \text { ) }\end{array}$

a) and b) based on observation $\left.\begin{array}{c}\text { a) } 0.2-0.5 \mathrm{~g} \mathrm{P} / \mathrm{m}^{2} \cdot \text { year } \\ 5-10 \mathrm{~g} \mathrm{~N} / \mathrm{m}^{2} \cdot \text { year }\end{array}\right\}$ VOLLENWEIDER [21]

b) consider lake characteristics (depth), e.g.,

a) and b) based on observation
3. Mathematical Models a) Streeter and Phelps [18]

$$
\frac{d D}{d t}=h_{1} L-h_{2} D
$$

plug flow reactor (PFR) assumed, assumes continuous stirred-tank rcactor (CSTR), $k_{1}, k_{2}$ determined from field data and MUELLER [11]

b) Diffusion equation, one dimension (O'Connor [9])

$$
\frac{\partial[C]}{\partial t}+v \frac{\partial[C]}{\partial x}=\frac{\partial}{\partial x} E_{\mathrm{x}} \frac{\partial[C]}{\partial x}
$$

$E_{x}$ introduced to account for flow deviations from PFR model in $\pm \Sigma r$ (e.g., $\mathrm{NH}_{4}^{+}+\mathrm{O}_{2} \rightarrow$ $\mathrm{NO}_{3}^{-}$, photosynthesis, sluclge (leposits), $k_{2}$ can now be estimated without field D.O. data using a physical model.

Some problems - many loadings (inputs) are diffuse, $k_{1}$ depends upon type of organic matter, first orcler $\mathrm{BOD}$ equation $\left(r_{\mathrm{BOD}}=k_{1} L\right)$ not adequate model in all cases, many coefficients ( $E_{x}$, etc.) must be determined from field data, occasional need for two and three-dimensional model.
Piontelli and Tonolli [13], Vollenweider [22]

$\frac{d\left[M_{w}\right]}{d t}=\frac{J}{\bar{z}}-(\sigma+0)\left[M_{w}\right]$ $\varrho_{e f f}$ can be introduced to describe deviations from CSTR model.

Some problems - many loadings are diffusc, hydraulic model (CSTR) may not characterize stratified lake, only sedimentation and hydraulic discharge (washout) are included as reactions, all coefficients $\left(\sigma, \varrho_{\text {eff }}\right)$ must be determined from ficld data. Of greatest significance the model predicts that the nonconservative behavior of a substance (e.g. phosphorus) will lead to its disappearance from the lake waters. In fact, the opposite effect is noticed in many lakes; nonconservative behavior can lead to an accumulation of a substance in lake waters. 
4. Optimiza- Many attempts on regional scale, tion some successful. Advances due to 1. development of computer,

2. existence at a relatively sound technological function (the physical model provided by the diffusion equation) and 3. perhaps to the simple objective (minimum D.O. $=y)$.

\begin{tabular}{|c|c|c|c|c|}
\hline $\begin{array}{l}\text { Nomen- } \\
\text { clature }\end{array}$ & $\begin{array}{l}D \\
L \\
k_{1} \\
k_{2} \\
{[C]} \\
v \\
E_{x}\end{array}$ & $\begin{aligned}= & \text { D. } O . \text { Deficit }(\mathrm{mg} / \mathrm{l}) \\
= & \text { BOD remaining }(\mathrm{mg} / \mathrm{l}) \\
= & \text { deoxygenation coef. }\left(\text { days }^{-\mathbf{1}}\right) \\
= & \text { reaeration coef. }\left(\text { days }^{-1}\right) \\
= & \text { concentration of } \\
& \text { substance }(\mathrm{mg} / \mathrm{l}) \\
= & \text { water velocity at } x, \\
& t \text { (miles/day) } \\
= & \text { longitudinal mixing coef. } \\
& \left(\text { miles }^{2} / \text { day) }\right.\end{aligned}$ & $\begin{array}{l}x \\
\gamma \\
t \\
{\left[M_{w}\right]} \\
J \\
\sigma \\
\varrho \\
\bar{z} \\
t\end{array}$ & $\begin{aligned}= & \text { distance along stream length (miles) } \\
= & \text { reaction rate }(\mathrm{mg} / \mathrm{l} \text {-day) } \\
= & \text { time (days) } \\
= & \text { concentration of } M\left(\mathrm{~g} / \mathrm{m}^{3}\right) \\
= & \text { flux of } M \text { to lake }\left(\mathrm{g} / \mathrm{m}^{2} \cdot \text { year) }\right. \\
= & \text { sedimentation coef. (years }-1) \\
= & \left.\text { flow coef. (years }{ }^{-1}\right)=Q / V, \text { where } \\
& Q=\text { hydraulic inflow and } V=\text { lakevolume } \\
= & \text { mean lake depth }(\mathrm{m}) \\
= & \text { time (years) }\end{aligned}$ \\
\hline
\end{tabular}

Similar difficulties are encountered when one seeks to express 'oligotrophic' and 'eutrophic' in quantitative terms. Numerous criteria have been used by others, including net productivity, nutrient loading, oxygen concentration and consumption in the hypolimnion, total supply of organic matter, biomass, Secchi depth, and species diversity. This latter characteristic (a decline in diversity as one moves along an oligotrophic-eutrophic scale) is particularly significant in that it can reflect the ability of an aquatic system to resist disturbances from new pollutants, including accidental or shock loadings of hazardous materials. Attention is directed here, however, towards the supply of nutrients to the epilimnion of a lake. It is likely that models for several other parameters can be based on this nutrient supply. The relationship between nutrient supply and species diversity (stability) may continue to be developed by observation in the immediate future.

The concentration of dissolved oxygen has long been used extensively as a measure of the acceptability of water quality in streams (Table 1). Typically a stream containing $4 \mathrm{mg} / 1$ or more of $D . O$. is considered to be relatively unpolluted; concentrations of oxygen less than this value are considered unsatisfactory. The use of such a D.O. criterion is based on maintaining a satisfactory environment for fish; water of such quality is also frequently acceptable for human recreational uses. The D.O. in a stream varies throughout the year; a critical period occurs, usually during the summer, when minimum oxygen concentrations are observed. A similar approach has been used to characterize water quality in lakes, with the concentrations of nutrients (usually nitrogen and phosphorus) replacing D. O. as criteria of water quality. SAWYER [17] has noted that concentrations of $\mathrm{N}$ and $\mathrm{P}$ less than 300 and $10 \mu \mathrm{g} / \mathrm{l}$, respectively, during a critical period before the summer stagnation generally produce satisfactory water quality throughout the year. At concentrations in excess of these levels the waters are likely to deteriorate. 
One is then led to ask 'How are these criteria to be met?' Early work in streams focused on the BOD loading, expressed in terms of the dilution of BOD by stream flow. Suitable loading rates were developed empirically from field observations (e.g., $4 \mathrm{cfs} / 1,000$ people). These loading rates were refined to account for the physical characteristics of the stream (sluggish, rapid, shallow, deep, etc.). Similar trends can be observed for lakes in the recent limnological literature. For example, VollenWEIDER [21] expresses nutrient loading in terms of the rate of supply of nutrient to the lake per unit of lake surface area. Loading rates of less than 0.2 to $0.5 \mathrm{gram} / \mathrm{P} / \mathrm{m}^{2}$ per year and 5 to $10 \mathrm{~N} / \mathrm{m}^{2}$ per year are considered to permit oligotrophic conditions. Higher loading rates lead to eutrophic conditions which are usually considered less desirable. These loading rates may be refined (Table 1) to reflect the influence of lake depth noted earlier by RAwson [14]. As in the approach described above for streams, these recommendations are based upon field observations.

In 1925 Streeter and Phelps [18] formulated a mathematical model for the dissolved oxygen deficit in a stream (see also Table 1):

$$
\frac{d D}{d t}=k_{1} L-k_{2} D
$$

where $D$ is the dissolved oxygen deficit in a stream at a time $(t)$ downstream from a continuous point source of $\mathrm{BOD}, L$ is the $\mathrm{BOD}$ remaining in the stream after the time $(t), k_{\mathbf{1}}$ is a deoxygenation coefficient, and $k_{\mathbf{2}}$ is a reaeration coefficient. This model reflects in a quantitative way the balance between oxygen demand (BOD) and oxygen supply, and has proved to be considerably more useful than simple BOD loading rates for evaluating and predicting water quality in streams. Several assumptions are made in formulating the model. For example, the model assumes that the flow pattern in the stream can be characterized by considering the stream as a plug-flow reactor (PFR), and that conditions are at a steady state. For many years the reaction coefficients $\left(k_{1}\right.$ and $k_{2}$ ) were determined from BOD and D.O. data obtained in the field. More recently (e.g., O'CONNOR and DoBBINs [10]), it has been possible to estimate the reaeration coefficient using a semitheoretical physical model involving stream velocity and depth. The Streeter-Phelps equation has frequently been modified to fit real systems by changing the coefficients or adding new ones.

An analogous approach is evolving in the modeling of lakes. VOLLENwEIDER [22], extending earlier work by PIONTELLI and ToNolli [13], formulates the following relationship (see also Table 1 )

$$
\frac{d\left[M_{w}\right]}{d t}=\frac{J}{\bar{z}}-(\sigma+\varrho)\left[M_{w}\right]
$$

Here $\left[M_{w}\right]$ is the concentration of substance $M$ in the lake at time $t, J$ is the rate of input of $M$ to the lake (e.g., gram $/ \mathrm{m}^{2}$ per year), $\bar{z}$ is the mean depth, and $\sigma$ is an empirically determined sedimentation coefficient. The hydraulic coefficient $(\varrho)$ is equal to $Q / V\left(1 / \bar{t}_{\mathrm{H}_{2} \mathrm{O}}\right)$, where $Q$ is the flow rate, $V$ is the lake volume, and $\bar{t}_{\mathrm{H}_{2} \mathrm{O}}$ is the hydraulic detention time. This model reflects the balance between the input of some material $M$ (e.g., phosphorus) from the land, and the output of $M$ in the lake discharge and to the lake sediments. The model considers that the concentration of $M$ in the lake is the 
same at all points; this assumes that the lake may be considered as a continuous stirred-tank reactor (CSTR). To provide a better fit with field observation, VoLLENWEIDER [22] has modified the hydraulic coefficient and added an additional sedimentation coefficient.

In stream analysis the Streeter-Phelps equation (1a) was formulated in a more general form after a few decades of development (e.g., O'CONNOR [9]). The resulting relationship, termed the diffusion equation, may be written in one-dimensional form as follows (see also Table 1 ):

$$
\frac{\partial[\mathrm{C}]}{\partial t}+v \frac{\partial[\mathrm{C}]}{\partial x}=\frac{\partial}{\partial x} E_{x} \frac{\partial[\mathrm{C}]}{\partial x} \pm \Sigma r
$$

Here $[\mathrm{C}]$ is the concentration of a substance $\mathrm{C}$ at some time $(t)$ and at some point $(x)$ along the length of a stream, $v$ is the stream velocity at $x, E_{x}$ is the longitudinal mixing coefficient at $x$ and $\Sigma r$ represents the reactions (production and destruction) of $C$ in the stream. $E_{x}$ in introduced to account for deviations from the PFR hydraulic model which occur in tidal rivers and estuaries; it must be evaluated from field data (salinity distributions, dye studies). Many different reactions have been included in the term $2 r$. Depending upon the system under study, photosynthesis, sludge deposits, and nitrification have been found to equal the effects of carbonaceous BOD $\left(r=-k_{1} L\right)$ and atmospheric reaeration $\left(r=k_{2} D\right)$ on the dissolved oxygen balance.

Some problems still remain in formulating a mathematical model for the oxygen balance in a stream. Many loadings (e.g., storm and combined sewer discharges) are diffuse, difficult to locate, and are not easily measured. Suitable relationships for some pertinent reaction rates (e.g., photosynthesis) are not well defined. Even the BOD reaction rate is only approximate since the rate of biological utilization of oxygen depends upon the kind of substrate and the population of organisms, while both of these parameters are not included directly in the BOD reaction rate formulation. In some cases two-dimensional models have been required. Nevertheless, mathematical models for the oxygen balance in streams have been formulated and used successfully for predictive purposes by numerous investigators.

Many attempts at optimizing water quality in streams and estuaries on a regional scale have been attempted; some have been quite successful. Such advances are due 1. to developments in numerical analysis and computers, 2. to the existence of a relatively sound 'technological function' [the diffusion equation (2a)], and perhaps 3 . to the use of simple objectives (e.g., minimizing the cost of achieving a particular minimum concentration of dissolved oxygen).

Unlike developments in stream analysis [compare equations (1a) and (2a)], a refinded and generalized version of Vollenweider's model for lakes [equation (1b)] is not yet available. Considering the thirty-five years required to generalize the StreeterPhelps equation and the continuing work in the area of stream and estuarine analysis, it seems likely that some time will be required to develop models for water quality in lakes which can compare in utility and predictive ability with presently available models for streams. This is not because of lack of effort or ability on the part of investigators in the limnological field; rather it derives from the greater complexity of pertinent phenomena in lakes. 
The remainder of this paper will formulate an approach to the development of predictive models in lakes. This approach will follow the Streeter-Phelps-O'Connor developments described herein and summarized in Table 1. The presentation will center on 1. a carbon budget for a lake, 2. a phosphorus budget for a lake, and 3. some field observations of the Vierwaldstättersee (Lake of Lucerne) and a segment of this lake, the Horwer Bucht (Horw Bay).

Many of the statements in the remainder of this paper are hypotheses or are based on hypotheses. The writer has chosen not to overuse the subjunctive mood. The reader is asked to recall for himself the hypothetical nature of the material.

\section{A carbon model}

A carbon model for lakes is considered here because 1 , it is a scientifically interesting problem, 2. carbon may be the limiting nutrient in some lakes, 3. some terms in a carbon model are needed for use in models for other substances, 4 . development and confirmation of a carbon model assists in the confirmation of other models containing some similar terms, and 5 . the carbon inputs to a lake are likely to be relatively constant, so that simple steady-state models may be useful.

Schematic diagrams for the carbon flows in a lake are presented in Fig. 1. Conditions during a summer stagnation period are illustrated in Fig. 1A. Here it is assumed that all surface runoff into the lakes enters the epilimnion, that no significant groundwater flows occur, and that direct rainfall to the lake surface equals evaporation. Conditions in a lake which circulates throughout the winter are presented in Fig. 1B. Here it is assumed that the lake is completely mixed (i.e., a CSTR model may be used).

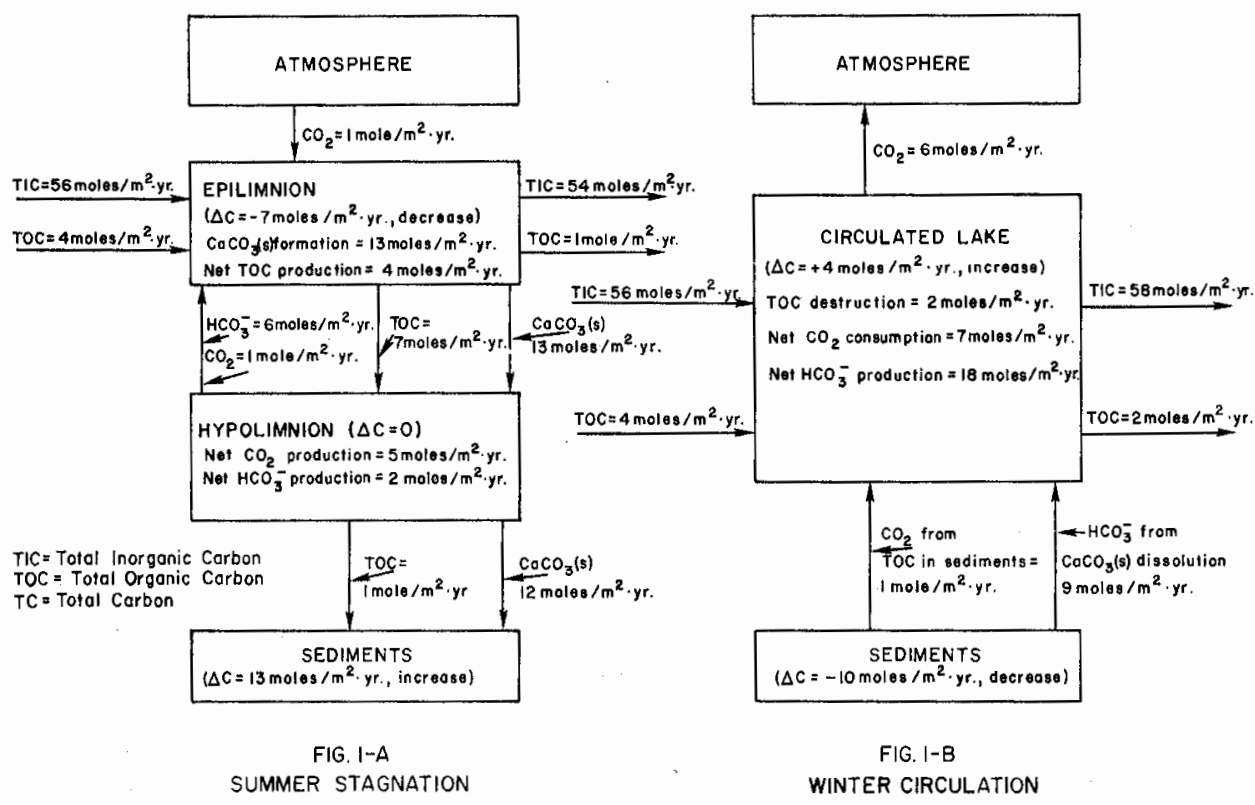

Fig. 1. Preliminary estimate of carbon budget for Vierwaldstättersee. 
These assumptions are made to simplify this presentation, and because they are also useful approximations for the Vierwaldstättersee which will be discussed subsequently. Appropriate modifications can be made for other situations (e.g., TAKAHASHI et al. [20]).

\section{The atmosphere-water interface}

Carbon $\left(\mathrm{CO}_{2}\right)$ may be transported across the atmosphere-water interface. The direction of this transport depends upon whether the upper region of the lake is undersaturated or oversaturated with respect to $\mathrm{CO}_{2}$; this is a thermodynamic question. Neglecting temperature and activity corrections, one needs measurements of two of the following: alkalinity, $\mathrm{pH}$, total inorganic carbon (TIC) and dissolved carbon dioxide $\left(\mathrm{H}_{2} \mathrm{CO}_{3}^{*}\right)$. Typically, alkalinity and $\mathrm{pH}$ are measured and concentrations of dissolved carbon dioxide are calculated using these measurements. Some difficulties can arise here, because $1 . \mathrm{pH}$ is difficult to measure in the field, 2. diurnal variations can be significant, and 3. determinations of alkalinity made on unfiltered samples may be too high due to dissolution of colloidal $\mathrm{CaCO}_{3}(\mathrm{~s})$ during the acidimetric titration. For $\mathrm{H}_{2} \mathrm{CO}_{3}^{*}$ calculations, the problem of $\mathrm{pH}$ measurement is quite significant, since the concentration of $\mathrm{H}_{2} \mathrm{CO}_{3}^{*}$ varies considerably with $\mathrm{pH}$ in the range frequently encountered in lakes ( $\mathrm{pH}$ from 7.5 to 8.5). It is interesting to note that oceanographers often measure TIC and $\mathrm{H}_{2} \mathrm{CO}_{3}^{*}$ directly, and then calculate $\mathrm{pH}$ and alkalinity from these measurements (e.g., Li et al. [7]).

The upper region of a lake is generally not at equilibrium with carbon dioxide in the atmosphere. Typically it may be undersaturated during the summer while the entire lake is oversaturated during a winter circulation. One must then consider the rate at which $\mathrm{CO}_{2}$ is transported across the lake surface. Answers to this question involve experimental difficulties. Following practice in environmental engineering and also the work of ODUM [12], one may write

$$
J_{\mathrm{CO}_{2}}=K \bar{z}\left[\left[\mathrm{H}_{2} \mathrm{CO}_{3}^{*}\right]_{s}-\left[\mathrm{H}_{2} \mathrm{CO}_{3}^{*}\right]\right] \text {. }
$$

Here $J_{\mathrm{CO}_{2}}$ is the net flux of carbon dioxide to or from the lake surface, $K$ is a gas transfer coefficient, $z$ is the mean depth of the epilimnion in summer or the entire lake in a circulation period, and $\left[\mathrm{H}_{2} \mathrm{CO}_{3}^{*}\right]_{s}$ and $\left[\mathrm{H}_{2} \mathrm{CO}_{3}^{*}\right]$ are the saturation and actual concentrations of $\mathrm{CO}_{2}$ in the epilimnion or the entire lake, respectively. Determination of $K$ or the product $K \bar{z}$ can be made using the method described by ODUm [12]. This procedure involves diurnal measurements of $\left[\mathrm{H}_{2} \mathrm{CO}_{3}^{*}\right]$ and/or $\left[\mathrm{O}_{2}\right]$ in the water. The gas transfer coefficient may then be obtained from the night-time variations of the measurements if the respiration rate is known. Alternatively, the predawn and sunset values of $\left[\mathrm{H}_{2} \mathrm{CO}_{3}^{*}\right]$ or $\left[\mathrm{O}_{2}\right]$ may be used to estimate $K$ (ODUm [12]). Takarashi et al. [20] have used the increase in atmospheric ${ }^{14} \mathrm{C}$ resulting from the testing of nuclear bombs to estimate the exchange of $\mathrm{CO}_{2}$ across the water-air interface of Green Lake in New York, USA.

Lacking these experimental capabilities, one can still estimate the order of magnitude of this $\mathrm{CO}_{2}$ flux from other reported values for transfer rates and from a knowledge of $\left[\mathrm{H}_{2} \mathrm{CO}_{3}^{*}\right]$ in a lake. This procedure is used here; the results are presented in Table 2. The data presented in Table 2 were obtained by Dr. Gächter of the EAWAC for the Horwer Bucht of the Vierwaldstättersee. 
Table 2. Estimated exchange rates of carbon dioxide at the atmosphere-lake interface of the Horwer Bucht.

\begin{tabular}{|c|c|c|}
\hline Parameter & $\begin{array}{l}\text { Date } \\
14 \text { September } 1970 \text { (epilimnion } \\
\text { during summer stagnation) }\end{array}$ & $\begin{array}{l}6 \text { January } 1970 \text { (onset } \\
\text { of winter circulation) }\end{array}$ \\
\hline Alkalinity (eq/1) & $1.66 \times 10^{-3}$ & $1.80 \times 10^{-3}$ \\
\hline $\mathrm{pH}$ & 8.5 & 7.83 \\
\hline Temperature $\left({ }^{\circ} \mathrm{C}\right)$ & 16.8 & 5.0 \\
\hline$\left[\mathrm{H}_{2} \mathrm{CO}_{3}^{*}\right]_{s}($ moles $/ 1)$ & $1.41 \times 10^{-5}$ & $2.04 \times 10^{-5}$ \\
\hline$\left[\mathrm{H}_{2} \mathrm{CO}_{3}^{*}\right]($ moles $/ \mathrm{l})$ & $1.02 \times 10^{-5}$ (epilimnion) & $8.04 \times 10^{-6}$ \\
\hline $\begin{array}{l}\text { Extent of saturation, } \\
{\left[\mathrm{H}_{2} \mathrm{CO}_{3}^{*}\right] /\left[\mathrm{H}_{2} \mathrm{CO}_{3}^{*}\right]_{8}}\end{array}$ & 0.725 & 4 \\
\hline Exchange Rate (moles $\mathrm{CO}_{2} / \mathrm{m}^{2} \cdot$ year) & 1 (from atmosphere) & 6 (to atmosphere) \\
\hline
\end{tabular}

The exchange rates for $\mathrm{CO}_{2}$ presented in Table 2 are based on an assumed flux of atmospheric $\mathrm{CO}_{2}$ to the lake of 2 moles $/ \mathrm{m}^{2}$ per year in the winter and $4 \mathrm{moles} / \mathrm{m}^{2}$ per year in the summer. These values actually depend upon the transport coefficient across the lake surface $(K$, or $K \bar{z})$. The assumptions are based on the summary of TAKAHASHI et al. [20] who report values of $3.5 \mathrm{moles} / \mathrm{m}^{2}$ per year for Green Lake, 3 to 5 moles $/ \mathrm{m}^{2}$ per year for large closed-basin lakes, and $12 \mathrm{moles} / \mathrm{m}^{2}$ per year for the oceans. For example, under the conditions presented in Table 2, $\mathrm{CO}_{2}$ is leaving the lake 4 times as fast as it enters during the winter circulation, producing a net flux of $(4-1)(2)$ or 6 moles/m² per year of $\mathrm{CO}_{2}$ to the atmosphere. Results for summer and winter are used in the carbon model illustrated in Fig. 1.

\section{The epilimnion-hypolimnion interface}

Three fluxes are of concern across the epilimnion-hypolimnion interface: 1 . the downward flux of $\mathrm{CaCO}_{3}(\mathrm{~s})$ precipitated in the epilimnion, 2. the downward flux of organic carbon which was discharged into or produced within the epilimnion, and 3. the upward diffusive fluxes of inorganic carbon species $\left(\mathrm{TIC}=\mathrm{H}_{2} \mathrm{CO}_{3}^{*}+\mathrm{HCO}_{3}^{-}+\right.$ $\mathrm{CO}_{3}^{-2}$ ) which may be produced within the hypolimnion from mineralization of organic material and dissolution of $\mathrm{CaCO}_{3}(\mathrm{~s})$.

The flux of organic carbon to the hypolimnion

Estimates of the flux of organic carbon to the hypolimnion may be made in several ways. It may be evaluated directly by measurements at approximate depths in the lake. When aerobic conditions prevail it may be estimated from the oxygen consumption, phosphate production or nitrate production in the hypolimnion and the appropriate stoichiometric conversions. These estimates can be low if organic carbon is deposited in the sediments or they can be high if organic carbon deposited previously in the sediments is oxidized. Under anaerobic conditions it is possible to estimate the flux in a similar manner from sulfide production. The flux may also be calculated from $\mathrm{CO}_{2}$ production in the hypolimnion; in this case correction for the possible consumption of $\mathrm{CO}_{2}$ in the dissolution of $\mathrm{CaCO}_{3}(\mathrm{~s})\left[\mathrm{CaCO}_{3}(\mathrm{~s})+\mathrm{H}_{2} \mathrm{CO}_{3}=\mathrm{Ca}^{2+}+2 \mathrm{HCO}_{3}^{--}\right]$may be required. A mass balance of organic carbon in the epilimnion may be used; in this procedure one must measure organic carbon inputs and discharges, together with the net productivity. 
Consider the following example, which is loosely based on data reported for the Vierwaldstättersee by AMBÜHL [1] and obtained in the Horwer Bucht by Dr. Gächter. The main portion of the Vierwaldstättersee containing both the Kreuztrichter and the Horwer Bucht (see also Fig. 6) and discharging through the Reuss River at Lucerne will be assumed to have 15-meter epilimnion, a 5-meter thermocline and a 40-meter hypolimnion during the summer stagnation. Over the period of the summer stagnation (assumed as 6 months), the dissolved oxygen (D.O.) in the hypolimnion is observed to decrease by $3 \mathrm{mg} / \mathrm{l}$. Assume that 278 atoms of oxygen are required to liberate 106 molecules of $\mathrm{CO}_{2}$ in the mineralization of organic matter in the hypolimnion. The organic matter oxidized in the hypolimnion, which is a measure of the organic matter introduced from the epilimnion, may then be estimated as follows:

$$
3 \times 10^{-3} \frac{\mathrm{g} \mathrm{O}_{2}}{1} \cdot \frac{10^{3} \mathrm{l}}{\mathrm{m}^{3}} \cdot \frac{40 \mathrm{~m}}{0.5 \text { year }} \cdot \frac{106 \text { moles } \mathrm{C}}{16(278) \text { moles } \mathrm{O}} \simeq 6 \mathrm{moles} / \mathrm{m}^{2} \text { per year }
$$

This value ( 6 moles $/ \mathrm{m}^{2}$ per year) represents a minimum figure, since some organic carbon may be deposited in the lake sediments. It will be used here as a maesure of the difference between the input of organic carbon to the hypolimnion from the epilimnion, and the discharge of organic carbon from the hypolimnion to the sediments.

It is also useful to estimate the rate of production of organic matter in the epilimnion. This will be done here in two ways: 1 . from estimates of phosphorus inputs, and 2 . from ${ }^{14} \mathrm{C}$ measurements of productivity. Consider first the organic carbon which can be produced from the phosphorus inputs. An estimate of $30 \mathrm{~kg} P$ discharged per $\mathrm{km}^{2}$ of drainage area per year will be used here, following VOLLENWEIDER [21]. It is, of course, preferable to measure the phosphorus inputs to a lake directly. As discussed subsequently, this would be relatively easy for the Vierwaldstättersee. Alternatively, one could arrive at a better estimate from data describing population, land use, and fertilizer application.

The Vierwaldstättersec has a draining area of $2,253 \mathrm{~km}^{2}$ and a total surface of $114 \mathrm{~km}^{2}$. The $\mathrm{P}$ loading to the lake is then

$$
\frac{30 \mathrm{~kg}}{\mathrm{~km}^{2} \cdot \text { year }} \cdot \frac{2253 \mathrm{~km}^{2}}{114 \mathrm{~km}^{2}} \cdot \frac{10^{3} \mathrm{~g}}{\mathrm{~kg}} \cdot \frac{1 \mathrm{~km}^{2}}{10^{6} \mathrm{~m}^{2}} \simeq \frac{0.6 \mathrm{gP}}{\mathrm{m}^{2} \cdot \text { year }}
$$

and the production of organic carbon may be estimated as

$$
\frac{0.6 \text { gms } \mathrm{P}}{\mathrm{m}^{2} \cdot \text { year }} \cdot \frac{106}{31(1)} \simeq 2 \text { moles } / \mathrm{m}^{2} \text { per year }
$$

This calculation may represent a minimum estimate for while it assumes that all phosphorus which enters the lake is incorporated into organic matter, it also neglects possible recirculation of phosphorus from the hypolimnion. It is useful to note that $\mathrm{P}$ is the limiting nutrient in the Vierwaldstättersee.

Data obtained by GÄCHTER et al. [4] indicate that productivity as measured by ${ }^{14} \mathrm{C}$ uptake is in the order of $50 \mathrm{mg} \mathrm{C} / \mathrm{m}^{2}$ per hour during the summer. Assuming that this rate of carbon fixation was operative for 8 hours each day, one can estimate the production of organic carbon in the epilimnion as follows: 


$$
50 \cdot \frac{10^{-3} \mathrm{~g}}{\mathrm{~m}^{2} \cdot \text { hour }} \cdot \frac{24 \times 365 \text { hours }}{\text { year }} \cdot \frac{\text { mole }}{12 \mathrm{~g}} \cdot \frac{8}{24}=12 \text { molés } / \mathrm{m}^{2} \text { per year }
$$

It is probable that this estimate is high, due to the effects of respiration at night which are ignored. A more accurate estimate could be made using diurnal measurements and the techniques described by ODum [12]. Considering these maximum and minimum estimates (12 and 2 moles organic carbon produced $/ \mathrm{m}^{2}$ per year), a figure of 4 moles/ $\mathrm{m}^{2}$ per year is used in Fig. 1.A.

\section{The flux of calcium carbonate to the hypolimnion}

This transport, like the transport of $\mathrm{CO}_{2}$ across the atmosphere-water interface, can be approached profitably from both thermodynamic and kinetic standpoints. First one can ask -- 'Are the lake waters under or oversaturated with respect to the precipitation of calcium carbonate?' Here one needs the concentration of $\mathrm{Ca}^{2+}$, and again two of the following - alkalinity, $\mathrm{pH}$, TIC and $\left[\mathrm{H}_{2} \mathrm{CO}_{3}^{*}\right]$. Difficulties in obtaining and interpreting alkalinity and $\mathrm{pH}$ data have been described earlier. To this one can add the necessity of distinguishing between soluble $\mathrm{Ca}^{2+}$ and total calcium, which may include some colloidal $\mathrm{CaCO}_{3}(\mathrm{~s})$. The results of some thermodynamic calculations for a stratified lake are presented in Fig. 2. These involve alkalinity and $\mathrm{pH}$ data from the Horwer Bucht obtained by Gächter on 14 September 1970. Estimates of the actual amounts of calcium in the lake are based on determinations of calcium concentrations by Zobrist of the EAWAG performed on samples collected at a later date (7 July 1971). Nevertheless, the comparison suggests that the epilimnion is considerably oversaturated with respect to $\mathrm{CaCO}_{3}(\mathrm{~s})$, while the major portion of the hypolimnion is closer to equilibrium.

Results of calculations for a lake during the winter circulation are presented in Fig. 3. These results illustrate again (Fig. 3C) that the entire contents of the lake are oversaturated with respect to $\mathrm{H}_{2} \mathrm{CO}_{3}^{*}$ in winter. Although the calcium concentration in the lake has not been measured in winter, it is probably in the order of $2 \times 10^{-3} \mathrm{M}$. This suggests that the deviations from $\mathrm{CaCO}_{3}(\mathrm{~s})$ equilibrium in the main body of the lake are less pronounced during this period. The bottom of the lake may be undersaturated, leading to some dissolution of $\mathrm{CaCO}_{3}(\mathrm{~s})$ from the sediments (Fig. 3E).

Next we consider the rate of $\mathrm{CaCO}_{3}(\mathrm{~s})$ settling from the epilimnion to the hypolimnion during the summer stagnation. This flux can be evaluated directly by measurements at appropriate depths in the lake. An estimate can also be made on the basis of measurements of other inputs and outputs of $\mathrm{Ca}^{2+}$ in the epilimnion [change in $\mathrm{Ca}$ in epilimnion in time $(t)=$ input from land runoff - output in lake discharge \pm transport by diffusion across thermocline - sedimentation to hypolimnion]. If the actual rate of $\mathrm{CaCO}_{3}(\mathrm{~s})$ deposition in the sediments can be determined (e.g., by direct measurement, gravimetric analysis of sediment cores, or ${ }^{14} \mathrm{C}$ dating of the cores (see TAKAHASHI et al. [20]), one can evaluate the $\mathrm{CaCO}_{3}(\mathrm{~s})$ input to the hypolimnion from the epilimnion by a similar mass balance (the change in $\mathrm{Ca}$ in the hypolimnion over a time period $=$ the input of $\mathrm{CaCO}_{3}(\mathrm{~s})$ from the epilimnion \pm diffusion of $\mathrm{Ca}^{2+}$ across the thermocline - the output $\mathrm{CaCO}_{3}(\mathrm{~s})$ to the sediments). Such estimates are assisted by a knowledge of the extent to which the hypolimnion is at equilibrium with respect to solid $\mathrm{CaCO}_{3}$. 

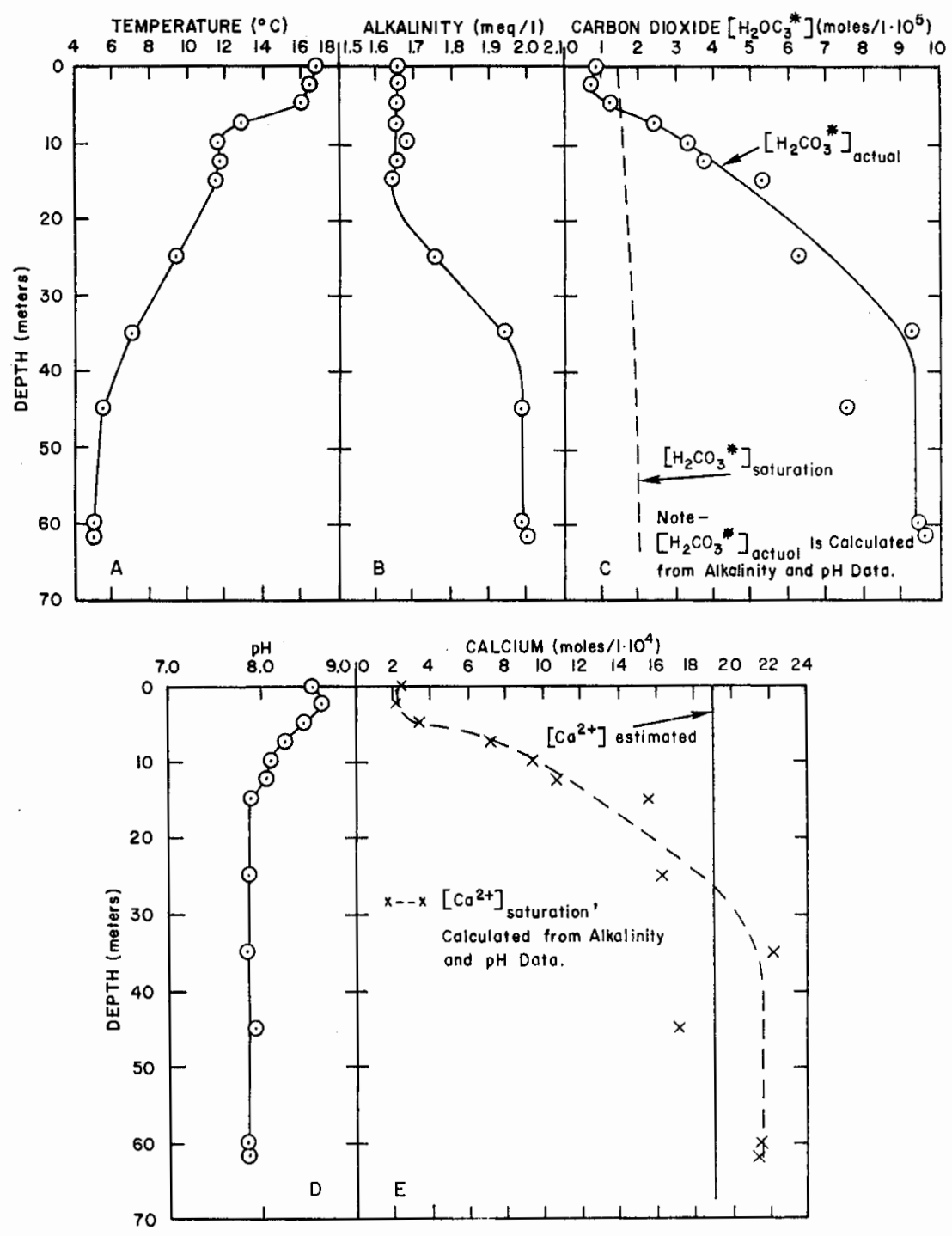

Fig. 2. Data and calculated results for Horwer Bucht, 14 September 1970 (summer stagnation).

Insufficient data are available to permit such calculations for the Vierwaldstättersee and the Horwer Bucht. To arrive at an estimate of the $\mathrm{CaCO}_{3}(\mathrm{~s})$ flux across the epilimnion-hypolimnion interface, let us assume that the decrease in alkalinity in the epilimnion during the summer stagnation is due to precipitation of $\mathrm{CaCO}_{3}(\mathrm{~s}) \mathrm{Ca}^{2+}+$ $\mathrm{CO}_{3}{ }^{2-}=\mathrm{CaCO}_{3}(\mathrm{~s})$, the precipitation of one mole of $\mathrm{CaCO}_{3}(\mathrm{~s})$ consumes 2 equivalents of alkalinity]. The changes in alkalinity at a depth of 5 meters in the Horwer Bucht during 1970 are shown in Fig. 4 ; note also the vertical distribution during the summer stagnation presented in Fig. $2 \mathrm{~B}$. It is, of course, possible that these variations reflect changes in the inputs to the lake, the utilization of $\mathrm{HCO}_{3}^{-}$by algae, or the exchange of $\mathrm{H}^{+}$ 


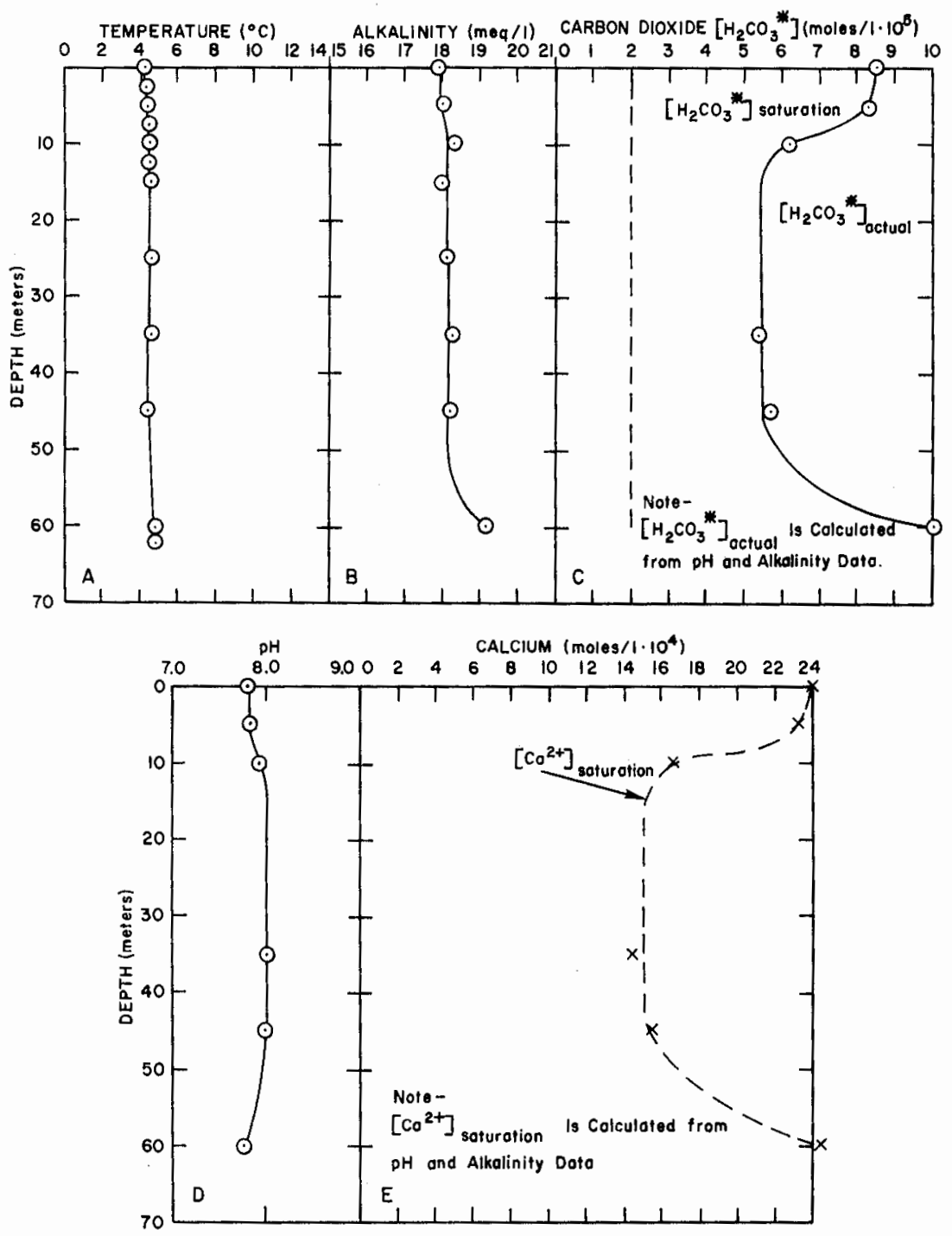

Fig. 3. Data and calculated results for Horwer Bucht, 1 January 1970 (beginning of winter circulation).

for cations by clays. It is interesting to note that a steady-state alkalinity concentration of about $1.65 \mathrm{meq} / \mathrm{l}$ is approached during the latter portion of the summer stagnation period. While this could be due to a limiting supply of calcium, it is also consistent with a steady-state balance between the removal of alkalinity from the epilimnion by precipitation of $\mathrm{CaCO}_{3}(\mathrm{~s})$ and the return of alkalinity $\left(\mathrm{HCO}_{3}^{-}\right)$from the hypolimnion by diffusion across the thermocline after a sufficient concentration gradient is developed. The subject of diffusion of materials across the thermocline is discussed subsequently. 


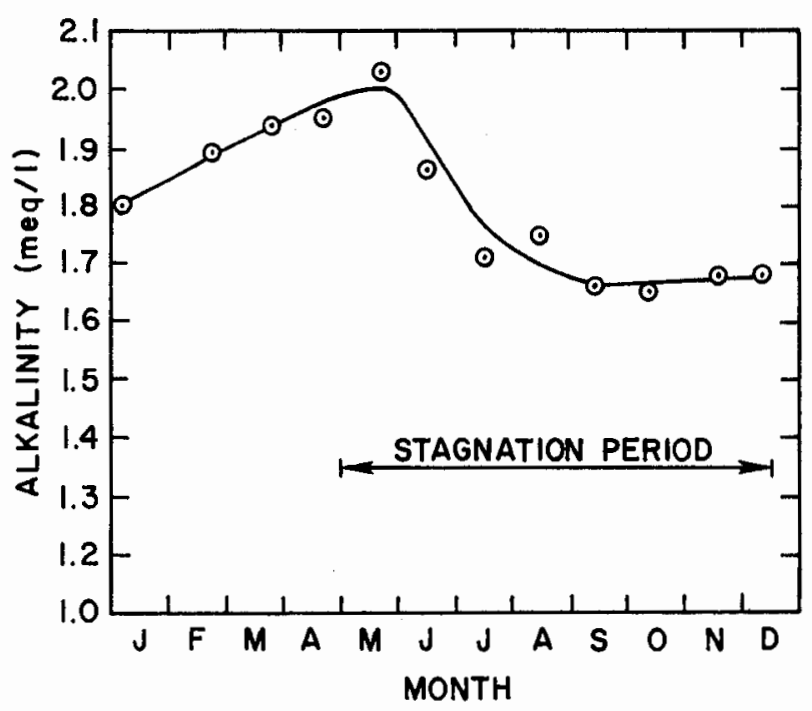

Fig. 4. Alkalinity of $5 \mathrm{~m}$ depth in Horwer Bucht, 1970.

In June, before an alkalinity gradient is sufficiently developed to produce a significant upward flux from the hypolimnion, the alkalinity is reduced by about $0.15 \mathrm{meq} / \mathrm{l}$ (Fig. 4). Assuming that the epilimnion in the main body of the lake is $1.5 \mathrm{~m}$ deep; this corresponds to a rate of production of $\mathrm{CaCO}_{3}(\mathrm{~s})$ in the epilimnion of

$$
\frac{0.15 \cdot 10^{-3} \text { moles } \mathrm{CaCO}_{3}}{2 \text { liter }} \cdot \frac{10^{3} 1}{\mathrm{~m}^{3}} \cdot \frac{1}{0.0833 \text { year }} \cdot 15 \mathrm{~m} \simeq 13 \frac{\text { moles }}{\mathrm{m}^{2} \cdot \text { year }} .
$$

The Vierwaldstättersee has a hydraulic detention time measured in years; it seems reasonable to assume that all of the $\mathrm{CaCO}_{3}(\mathrm{~s})$ produced in the epilimnion is transported to the hypolimnion by sedimentation (see Fig. 1).

The diffusive flux of soluble inorganic carbon

Concentration or activity gradients of many substances exist in a lake. Generally these gradients are most pronounced in the vertical direction. Such gradients give rise to a diffusive transport of materials in the direction of the gradient. Given these facts, it is then pertinent to examine whether the rate of transport of materials by diffusion is sufficiently rapid to affect chemical and biological processes in lakes. For any substance exhibiting a vertical concentration gradient one can write Fick's equation as follows, in the absence of advective transport and chemical reactions:

$$
J=k_{z} \frac{\partial[\mathrm{C}]}{\partial z}
$$

Here $J$ is the instantaneous flux (e.g., moles $/ \mathrm{m}^{2}$ per year) of material $\mathrm{C}$ through a horizontal unit area, $k_{z}$ is the vertical mixing coefficient, and $\partial[\mathrm{C}] / \partial z$ is the concentration gradient of $\mathrm{C}$ in the $z$ (depth) direction. It is useful to note that eddy diffusion is significantly greater than molecular diffusion in lakes (e.g., Hutchinson [5]). 
It is then necessary to evaluate $k_{z}$ as a function of depth. This can be done using observations of lake temperature as a function of depth and time during the stagnation period (e.g., Hutchinson [5], Lerman and Stiller [6]). The transport of conservative substances has also been used (e.g., the combination of salinity and temperature data to evaluate vertical advection and diffusion in the oceans, described by Munk [8]). In addition, radiotracers which decay but do not otherwise react can be employed to estimate vertical fluxes (e.g., the use of ${ }^{90} \mathrm{Sr}$ to evaluate vertical mixing in Green Lake, by TakaHASHI et al. [20]).

From temperature data obtained in the Horwer Bucht on 21 May 1970 and 17 August 1970, the results in Table 3 may be calculated using the methods of HuTCHINSON [5] and LERMAN and STILLER [6]. Errors in the calculated values of $k_{z}$ may be due 1. to the use of an incorrect model (e.g., neglect of advective velocities and heat sources) and 2. to errors due to random errors in temperature measurements. In this latter case the error in evaluating $k_{z}$ depends upon the time between obtaining successive temperature samples, the depth interval at which the temperatures are measured, and the instrumental capability to measure temperatures accurately (LERMAN and STILLER [6]). It is plausible that the results presented in Table 3 are correct within half an order of magnitude. Some results obtained by others are presented in Table 4 for comparison.

Table 3. Calculated values of $k_{z}\left(\mathrm{~cm}^{2} / \mathrm{sec}\right)$ for the Horwer Bucht.

\begin{tabular}{lll}
\hline Depth & $\begin{array}{l}\text { After Hutchinson [5] } \\
\text { (graphical method) }\end{array}$ & $\begin{array}{l}\text { After Lerman and StiLleR [6] } \\
\text { (numerical method) }\end{array}$ \\
\hline $6-8 \mathrm{~m}$ & & 0.056 \\
$8-12 \mathrm{~m}$ & 0.65 & 0.11 \\
$7-24 \mathrm{~m}$ & & \\
\hline
\end{tabular}

Table 4. Representative vertical mixing coefficients.

\begin{tabular}{|c|c|c|}
\hline Body of water & $k_{z}\left(\mathrm{~cm}^{2} / \mathrm{sec}\right)$ & Reference \\
\hline Cariaco Trench & 0.6 & REDField, Ketchum and RichaRds [15] \\
\hline Atlantic Ocean & 0.4 to 13.5 & $\begin{array}{l}\text { RILEY }[16] \text { quoted by REDFIELD, } \\
\text { KETCHUM and RICHARDS }[15]\end{array}$ \\
\hline \multicolumn{3}{|l|}{ Lake Tiberias } \\
\hline epilimnion & 0.74 to 19.2 & LFRMAN and STILLER [6] \\
\hline hypolimnion & 0.09 to 0.58 & \\
\hline \multicolumn{3}{|l|}{ Lake Mendota } \\
\hline epilimnion & 4.76 & DUtTON and BRYSON [3] \\
\hline thermocline & 0.73 & \\
\hline hypolimnion & 0.75 & \\
\hline \multicolumn{3}{|c|}{ West Hawk Lake (Manitoba) } \\
\hline epilimnion & 4.97 & DUTTON and BRYSON [3] \\
\hline thermocline & 0.06 & \\
\hline hypolimnion & 4.97 & \\
\hline
\end{tabular}


Based on the results presented in Tables 3 and 4 , it seems reasonable to assume a value for $k_{z}$ of $0.05 \mathrm{~cm}^{2} / \mathrm{sec}$ in the thermocline of the Vierwaldstättersee and the Horwer Bucht. If one then assumes an alkalinity gradient of $0.35 \times 10^{-3} \mathrm{eq} / 1$ (approximately equal to $0.35 \times 10^{-3}$ moles of $\left.\mathrm{HCO}_{3}^{-} / 1\right)$ across a 5 -meter thermocline, the diffusive flux of bicarbonate from the hypolimnion to the epilimnion at the end of the stagnation period may be estimated as follows:

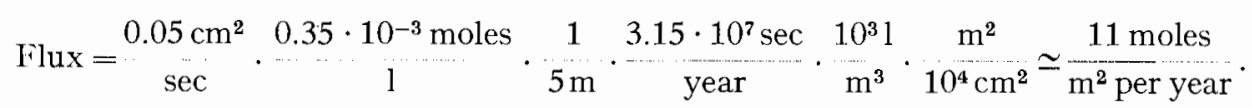

This estimate is less than the rate at which $\mathrm{CaCO}_{3}(\mathrm{~s})$ formation has been estimated to remove alkalinity from the epilimnion $\left(13\right.$ moles $\mathrm{CaCO}_{3} / \mathrm{m}^{2}$ per year $\times 2$ moles $\mathrm{HCO}_{3}^{-} /$ mole $\mathrm{CaCO}_{3}(\mathrm{~s})=26$ moles $/ \mathrm{m}^{2}$ per year). Nevertheless, considering the uncertainties in the value of $k_{z}$ and $\partial\left[\mathrm{HCO}_{3}^{-}\right] \partial z$ used here, it is plausible that the apparent steady state observed for the alkalinity in the epilimnion during the latter part of the summer stagnation (Fig. 4) is due to a balance between $\mathrm{CaCO}_{3}(\mathrm{~s})$ sedimentation and $\left[\mathrm{HCO}_{3}^{-}\right]$ diffusion. An average bicarbonate flux over the summer stagnation period of 6 moles/ $\mathrm{m}^{2}$ per year is used in Fig. $1 \mathrm{~A}$ based on the maximum rate of $11 \mathrm{moles} / \mathrm{m}^{2}$ per year at the end of the stagnation period.

It is useful to note here that the alkalinity gradient used in the previous calculation can depend upon the depth of the lake, and the degree of saturation of the hypolimnion with respect to $\mathrm{CaCO}_{3}(\mathrm{~s})$. Precipitation of $\mathrm{CaCO}_{3}(\mathrm{~s})$ reduces the alkalinity in the epilimnion, thereby creating a $\left[\mathrm{HCO}_{3}^{-}\right]$gradient. If the hypolimnion is also oversaturated, $\mathrm{CaCO}_{3}(\mathrm{~s})$ can precipitate therein, reduce the gradient, and lower the diffusive flux of $\mathrm{HCO}_{3}^{-}$to the epilimnion. If the hypolimnion is just at equilibrium with $\mathrm{CaCO}_{3}(\mathrm{~s})$ the gradient will be unaffected. If, however, the hypolimnion is undersaturated with respect to $\mathrm{CaCO}_{3}(\mathrm{~s})$, then some or all of the $\mathrm{CaCO}_{3}$ formed in the epilimnion can dissolve in the hypolimnion, thereby increasing the $\mathrm{HCO}_{3}-$ gradient and increasing the upward carbon flux. The extent to which the gradient is increased will depend upon the extent to which resolubilized carbon is diluted in the hypolimnion; large (deep) lakes might provide greater dilution and exhibit smaller fluxes of $\mathrm{HCO}_{3}^{-}$ upward to the epilimnion.

The diffusive flux of $\mathrm{CO}_{2}$ from the hypolimnion to the epilimnion may be evaluated in a similar manner. A vertical concentration gradient will exist due to uptake of $\mathrm{CO}_{2}$ by photosynthesis in the epilimnion and the mineralization of organic carbon in the hypolimnion (e.g., Fig. 2C). The upward flux can be estimated from the vertical gradient of $\mathrm{CO}_{2}$. Analyses of the data in Fig. $2 \mathrm{C}$ suggest an upward flux of $\mathrm{CO}_{2}$ to the epilimnion which is in order of $5 \mathrm{moles} / \mathrm{m}^{2}$ per year. This figure is probably not realistic; reaction of $\mathrm{CO}_{2}$ with $\mathrm{CaCO}_{3}$ (s) can make direct application of equation (4) invalid.

An approximate estimate of the upward flux of $\mathrm{CO}_{2}$ into the epilimnion can be made by considering the $\mathrm{CO}_{2}$ production in the hypolimnion. This has been estimated earlier as 6 moles $/ \mathrm{m}^{2}$ per year. Assuming that the hypolimnion is 40 meters deep, that $1 \mathrm{~mole} / \mathrm{m}^{2}$ per year of this $\mathrm{CO}_{2}$ is used to dissolve $\mathrm{CaCO}_{3}(\mathrm{~s})$, and that the $\mathrm{pH}$ is sufficiently low $(\mathrm{pH}<8.3)$ so that the rest of $\mathrm{CO}_{2}$ added to the lake remains as $\mathrm{H}_{2} \mathrm{CO}_{3}^{*}$, one can estimate the increase in $\mathrm{CO}_{2}$ in the hypolimnion over the summer stagnation (0.5 year) as follows 


$$
\Delta\left[\mathrm{H}_{2} \mathrm{CO}_{3}^{*}\right]=\frac{5 \text { moles }}{\mathrm{m}^{2} \cdot \text { year }} \cdot \frac{1}{40 \mathrm{~m}} \cdot \frac{1 \mathrm{~m}^{3}}{10^{3} \mathrm{l}} \cdot 0.5 \text { year }=6.3 \cdot 10^{-5} \frac{\text { moles }}{1} \text {. }
$$

Assume further that $\left[\mathrm{H}_{2} \mathrm{CO}_{3}^{*}\right]$ in the epilimnion is $0.7 \times 10^{-5}$ moles/l and that transfer occurs across a thermocline 5 meters thick with a vertical mixing coefficient $\left(k_{z}\right)$ of $0.05 \mathrm{~cm}^{2} / \mathrm{sec}$. The flux of $\mathrm{CO}_{2}$ to the epilimnion is then estimated as follows:

$$
\begin{aligned}
\text { Flux } & =\frac{0.05 \mathrm{~cm}^{2}}{\mathrm{sec}} \cdot \frac{[6.3-0.7] \cdot 10^{-5}}{5 \mathrm{~m}} \cdot \frac{\text { moles }}{1} \cdot \frac{3.15 \cdot 10^{7} \mathrm{sec}}{\text { year }} \cdot \frac{10^{3} 1}{\mathrm{~m}^{3}} \cdot \frac{\mathrm{m}^{2}}{10^{4} \mathrm{~cm}^{2}} \\
& \simeq 2 \text { moles } / \mathrm{m}^{2} \text { per year. }
\end{aligned}
$$

Half of this value ( $1 \mathrm{~mole} / \mathrm{m}^{2}$ per year) is used as an average for the summer stagnation period in Fig. $1 \mathrm{~A}$.

\section{The sedimentwater interface}

Carbon may be transported across the sediment-water interface by a) settling of $\mathrm{CaCO}_{3}(\mathrm{~s})$ to the sediments, b) dissolution of $\mathrm{CaCO}_{3}(\mathrm{~s})$ already in the sediments, c) settlement of organic carbon and d) mineralization of organic matter already in the sediments. The direction the transport of inorganic carbon associated with $\mathrm{CaCO}_{3}(\mathrm{~s})$ depends upon the extent to which the bottom lake waters are saturated with $\mathrm{CaCO}_{\mathbf{3}}(\mathrm{s})$. Since most organic materials are thermodynamically unstable in water, there will be an upward flux of carbon from the sediments which will depend to some extent on the amount of organic material which is there.

The effects of $\mathrm{CaCO}_{3}(\mathrm{~s})$

Here one again first answers the thermodynamic question: "To what extent are the bottom lake waters in equilibrium with $\mathrm{CaCO}_{3}(\mathrm{~s})$ ?' The data presented in Fig. $2 \mathrm{E}$, while not completely convincing, do suggest that the hypolimnetic waters of the Horwer Bucht do not deviate significantly from $\mathrm{CaCO}_{3}(\mathrm{~s})$ equilibrium during the summer stagnation. The data presented in Fig. $3 \mathrm{E}$ indicate the possibility that the sediment-water interface is somewhat undersaturated with respect to $\mathrm{CaCO}_{3}$ during the winter circulation. It is useful to recall that the data in Fig. $2 \mathrm{E}$ and $3 \mathrm{E}$ could be interpreted more rigorously if data for soluble and total calcium were available.

One next considers the rate of sedimentation or dissolution of $\mathrm{CaCO}_{3}(\mathrm{~s})$. Settling of $\mathrm{CaCO}_{3}(\mathrm{~s})$ can be evaluated by direct measurement at the sediment-water interface, or by analysis of sediment cores. Alternatively. a mass balance of calcium about the hypolimnion may be sued. Lacking these data, the following estimates are made for the Vierwaldstättersee. During the summer stagnation, the rate of $\mathrm{CaCO}_{3}(\mathrm{~s})$ deposition will not exceed the rate at which $\mathrm{CaCO}_{3}(\mathrm{~s})$ enters the hypolimnion from the epilimnion, since the hypolimnion is probably not oversaturated with respect to $\mathrm{CaCO}_{3}$ (Fig. 2E). This sets an upper limit for the deposition rate of 13 moles $/ \mathrm{m}^{2}$ per year. Considering that $\mathrm{CO}_{2}$ production from decomposing organic matter $\left(6 \mathrm{moles} / \mathrm{m}^{2}\right.$ per year) may be sufficient to produce some slight undersaturation in the hypolimnion, it will be assumed that $1 \mathrm{~mole} / \mathrm{m}^{2}$ per year of $\mathrm{CaCO}_{3}(\mathrm{~s})$ will be dissolved by $1 \mathrm{~mole} / \mathrm{m}^{2}$ of $\mathrm{CO}_{2}$, leaving a net flux of $12 \mathrm{moles} / \mathrm{m}^{2}$ per year of calcium carbonate to the sediments, and a residual of 5 moles $/ \mathrm{m}^{2}$ per year of $\mathrm{CO}_{2}$ added to the hypolimnion. These estimates 
are used in Fig. 1A. They could readily be refined by reliable $\left[\mathrm{Ca}^{2+}\right]$ and total calcium measurements on the lake waters.

The alkalinity in the Vierwaldstättersee is observed to increase during the winter circulation, suggesting the possible dissolution of $\mathrm{CaCO}_{3}(\mathrm{~s})$ from the sediments. Data obtained at a depth of $5 \mathrm{~m}$ in the Horwer Bucht are presented in Fig. 4. Considering data obtained throughout the depth of the Horwer Bucht, an estimate of a $0.15 \mathrm{meq} / 1$ increase in alkalinity during the winter circulation in the Vierwaldstättersee is obtained. Using a mean lake depth of 60 meters, the rate of dissolution of $\mathrm{CaCO}_{3}(\mathrm{~s})$ from the sediments is then estimated as

$$
\frac{0.15 \times 10^{-3} \mathrm{eq}}{1} \cdot \frac{1 \mathrm{~mole} \mathrm{CaCO}_{3}(\mathrm{~s})}{2 \mathrm{eq}} \cdot \frac{10^{3} 1}{\mathrm{~m}^{3}} \cdot 60 \mathrm{~m} \cdot \frac{1}{0.5 \text { years }}=9 \text { moles } / \mathrm{m}^{2} \text { per year } .
$$

This estimate is used in Fig. 1B; it is somewhat less than the estimated deposition rate during the summer stagnation period ( $12 \mathrm{moles} / \mathrm{m}^{2}$ per year). This very approximate analysis suggests that $\mathrm{CaCO}_{3}(\mathrm{~s})$ is accumulated in the sediments of the Vierwaldstättersee at an annual rate of 3 moles $/ \mathrm{m}^{2}$ per year.

\section{The effects of organic carbon}

The transfer of organic carbon to the sediments during the summer stagnation can be evaluated 1 . by direct measurement, 2 . by examination of the sediments, and 3 . by a mass balance of carbon entering, leaving and accumulating is the hypolimnion. Available data for the Vierwaldstättersee do not permit the use of any of these methods. It is therefore arbitrarily assumed (Fig. 1A) that organic carbon deposits in the sediments at a rate of $1 \mathrm{~mole} / \mathrm{m}^{2}$ per year during the summer stagnation. This, combined with the previous estimate of 6 moles $/ \mathrm{m}^{2}$ per year of $\mathrm{CO}_{2}$ produced within the hypolimnion from the mineralization of organic carbon, yields an estimate of 7 moles $/ \mathrm{m}^{2}$ per year for the flux of TOC from the epilimnion to the hypolimnion (Fig. 1A).

Similar problems arise in considering the possible flux of $\mathrm{TOC}$ to the sediments during the winter circulation, or the possible release of $\mathrm{CO}_{2}$ and $\mathrm{CH}_{4}$ from the sediments during summer and winter. Here it is assumed that no organic matter is deposited in the sediments of the Vierwaldstättersee during the winter, and that one mole $/ \mathrm{m}^{2} \mathrm{per}$ year of $\mathrm{CO}_{2}$ is released from the sediments during that period. Possible addition of $\mathrm{CO}_{2}$ to the lake at the sediment-water interface during the winter circulation is suggested by the $\mathrm{pH}$ and $\left[\mathrm{H}_{2} \mathrm{CO}_{3}^{*}\right]$ profiles in $\mathrm{Fig} .3 \mathrm{D}$ and $\mathrm{C}$. The assumed value is, however, unsubstantiated at present.

\section{Inputs and discharges of carbon}

In many cases the inputs to lakes are numerous, diffuse, and difficult to measure while the principal discharge from a lake is generally at one location which is readily accessible. The lake-atmosphere and lake-sediment interfaces are considered separately in the paper. In the Vierwaldstättersee, about $85 \%$ of the water inputs are located at four points, and a single discharge exists via the Reuss River at Lucerne (see Fig. 6). The hydraulic inputs and discharge at these points have been measured for some time, but no measurements of carbon inputs or discharges are prescntly available.

One can estimate the discharge of inorganic carbon from the lake using $\mathrm{pH}$ and alkalinity data from the lake. Here the calculation will be simplified further by assum- 
ing that total inorganic carbon (TIC, moles/1) is numerically equal to the alkalinity (eq/1). The average values for the alkalinity in the lake discharge are taken as $\mathbf{1 . 7 5}$ meq/l and $1.90 \mathrm{meq} / 1$ during the summer and winter periods, respectively. The mean annual flow in the Reuss River at Lucerne is $111 \mathrm{~m}^{3} / \mathrm{sec}$ and the lake has a surface area of $114 \mathrm{~km}^{2}$. The discharge of inorganic carbon are then calculated as $54 \mathrm{moles} / \mathrm{m}^{2}$ per year and 58 moles $/ \mathrm{m}^{2}$ per year in the summer and winter, respectively. An average value (56 moles $/ \mathrm{m}^{2}$ per year) is assumed for the inputs of inorganic carbon in summer and winter (Fig. 1A and B).

Inputs and outputs of organic carbon are not known. A value of $7 \mathrm{moles} / \mathrm{m}^{2}$ per year has been arrived at previously for the flux of organic carbon from the epilimnion to the hypolimnion during the summer stagnation, together with an estimate of 4 moles $/ \mathrm{m}^{2}$ per year for the net rate of production of organic carbon in the epilimnion. Assuming that the organic carbon in the lake discharge is $1 \mathrm{~mole} / \mathrm{m}^{2}$ per year $(0.43$ $\mathrm{mg} / \mathrm{l}$ for $Q=111 \mathrm{~m}^{3} / \mathrm{sec}$, lake surface $\left.=114 \mathrm{~km}^{2}\right)$, the inflow of organic carbon is estimated as $(7+1-4)$ or 4 moles $/ \mathrm{m}^{2}$ per year (see Fig. $1 \mathrm{~A}$ ).

During the winter circulation it is assumed that the inputs to the lake remain unchanged at $56 \mathrm{moles} / \mathrm{m}^{2}$ per year and 4 moles $/ \mathrm{m}^{2}$ per year for the inorganic and organic components, respectively. It is assumed that no organic carbon is transported to the sediments during this period. Half of the organic carbon input is assumed to be discharged, and half is oxidized to carbon dioxide (Fig. 1B).

\section{Comments}

Based on the estimates presented in Fig. $1 \mathrm{~A}$ and $\mathrm{B}$, the following conclusions pertaining to the general subject of lake modeling are made:

1. Many different reactions have been considered, some physical (e.g., transport of soluble materials across the atmosphere - lake and epilimnion - hypolimnion interfaces), some chemical [e.g., precipitation and dissolution of $\left.\mathrm{CaCO}_{3}(\mathrm{~s})\right]$, and some biological (production and decomposition of organic matter). It seems probable that all of these reactions can contribute significantly to the general carbon balance of lakes. None can be considered negligible without supporting evidence.

2. Given this conclusion, it seems evident that the development of such lake models requires physical (engineering), chemical and biological insights. In other words, the efforts of individuals from several disciplines are required.

Although the model presented in Fig. $1 \mathrm{~A}$ and $\mathrm{B}$ is based on numerous assumptions and considerable extrapolations of data, the following conclusions which are specific to the Vierwaldstättersee are made.

1. While the cycling of carbon within the lake is largely due to biological activity, the major portion of the transport of carbon is associated with the precipitation and dissolution of $\mathrm{CaCO}_{3}(\mathrm{~s})$. It seems useful, therefore, to beginn measuring $\left[\mathrm{Ca}^{2+}\right]$ and total calcium in the lake at this time.

2. The inputs and outputs to the Vierwaldstättersee can be measured with a minimum of difficulty. Knowledge of the inputs and outputs of carbon (soluble and particulate, inorganic and organic) and calcium would be very useful to a general understanding of the lake process.

3. The lake acts as a pipe, carrying carbon from the aqueous inflow and the atmosphere to the sediments in the summer. During the winter this flow is reversed, so that 
carbon is carried from the sediments to the atmosphere and the lake discharge. Total carbon in the lake itself may decrease in summer $\left(-7\right.$ moles $/ \mathrm{m}^{2}$ per year $)$ and increase in winter $\left(+4\right.$ moles $/ \mathrm{m}^{2}$ per year $)$, as noted in Fig. $1 \mathrm{~A}$ and $\mathrm{B}$.

4. It is plausible that respiration $(R)$ is greater than photosynthesis $(P)$ in both summer and winter. During summer $P$ exceeds $R$ by 4 moles $/ \mathrm{m}^{2}$ per year in the epilimnion, but this is less than an estimated 6 moles $/ \mathrm{m}^{2}$ per year of $\mathrm{CO}_{2}$ production by respiration in the hypolimnion. During the winter a production of $\mathrm{CO}_{2}$ from organic matter is assumed which exceeds photosynthesis throughout the lake. Some of these $P$ and $R$ figures are based on very rough estimates; this conclusion should be viewed cautionsly until additional evidence is available.

\section{A phosphorus model}

Before proceeding to the development of a model for phosphorus in lakes, let us consider first the valuable previous work on lake modeling by VoLLENWEIDER [22] and by O'CONNOR and Muelser [11]. Vollenweider considers a lake as a well-mixed system (CSTR) receiving constant hydraulic and nutrient inputs [see equation (1b)]. A material of interest (e.g., total phosphorus) is removed from the lake in the outflow and by accumulation in the sediments. The settling process is described by a firstorder reaction in the model. Working independently, O'Connor and Mueller have arrived at a more general model. These authors also assume the entire lake to be a CSTR, and include the possibility that inputs from the land may vary with time. Both conservative substances and those which are removed from the system by first-order kinetics are considered. In addition, the model reflects the authors' interest in the Great Lakes, and so considers the case of 'lakes in series', where the discharge from one lake comprises a portion of the input to another.

These models have a significant drawback when used for phosphorus. Maximum phosphorus concentrations are predicted when the element is assumed to be conservative; according to the models, any reaction which phosphorus undergoes in the system can only decrease the concentration of total phosphorus $\left(\left[\mathrm{P}_{\mathbf{T}}\right]\right)$ in the system. In fact, however, the nonconservative behavior of phosphorus in many real systems actually leads to an accumulation of this element in lake waters. Frequently this accumulation is undesirable. Application of these models to phosphorus in lakes will therefore lead to predictions which do not agree with real systems and which can seriously overestimate the ability of lakes to assimilate this element.

The following approach using the general methodology described previously for the carbon model is proposed here in order to eliminate this difficulty. The lake is considered in two conditions, i. e., winter circulation and summer stagnation. A mass balance is formulated, using a CSTR flow model for the entire lake in winter and for the epilimnion in summer. Inputs and outputs are considered, and relationships for transport (e.g., diffusion) and reactions (e.g., sedimentation) are assumed. Non-steady state models are used because 1. the inputs of phosphorus to many lakes are increasing with time (e.g., АмвӥнL [1], Sтимм [19]), and 2. the composition of most lakes is changing throughout the year due to the formation and destruction of thermally stratified regions. 
It is useful and convenient to distinguish between the mean residence times of water $\left(\bar{t}_{\mathrm{H}_{2} \mathrm{O}}\right)$ and total phosphorus $\left(\bar{t}_{\mathbf{P}_{\mathrm{T}}}\right)$ in lakes. These are defined as follows:

$$
\bar{t}_{\mathrm{H}_{2} \mathrm{O}}=\frac{\text { mass of water in the lake }}{\text { mass flow rate of water into the lake }}=\frac{V}{Q}
$$

and

$$
\bar{t}_{\mathrm{P}_{\mathrm{\Gamma}}}=\frac{\text { mass of phosphorus in the lake }}{\text { mass flow rate of phosphorus into the lake }}=\frac{\mathrm{P}_{\mathrm{T}}}{d \mathrm{P}_{\mathrm{T}} / d t} .
$$

If total phosphorus acts conservatively, then ${\overline{\mathrm{H}_{2} \mathrm{O}}}={\overline{\mathrm{t}_{\mathrm{T}}}}_{\mathrm{T}}$. Should phosphorus be removed from the lake by some process (e.g., sedimentation), then $\bar{t}_{\mathrm{P}_{\mathrm{T}}}$ will be less than $\bar{t}_{\mathrm{H}_{2} \mathrm{O}}$. This case is considered by the Vollenweider-O'Connor and Mueller models. If phosphorus is held in the lake water by some process (e.g., exchange between the sediments and the lake or recirculation between the hypolimnion and the epilimnion), then $\bar{t}_{\mathrm{P}_{\mathrm{T}}}$ is greater than $\bar{t}_{\mathrm{H}_{2} \mathrm{O}}$. This involves an increase in the concentration of phosphorus in the lake and is frequently undesirable.

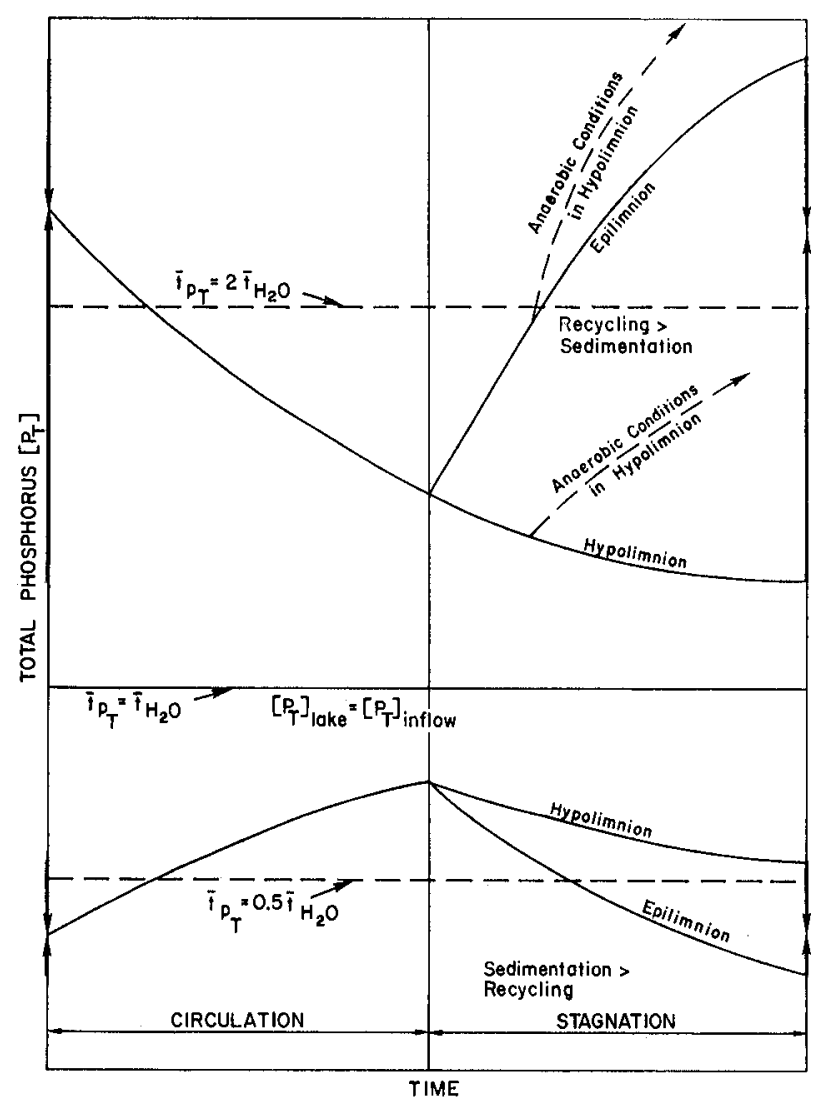

Fig. 5. Schematic diagrams of total phosphorus concentration on a function of time for $\overline{t_{p T}}<t_{\mathrm{H}_{2} \mathrm{O}}$ (bottom), $\bar{t}_{p \mathrm{~T}}=\bar{t}_{\mathrm{H}_{2} \mathrm{O}}$ (middle) and $\bar{t}_{p \mathbf{T}}>\bar{t}_{\mathrm{H}_{2} \mathrm{O}}$ (top). 
These three cases are illustrated schematically in Fig. 5. A hypothetical lake is considered which is characterized by a six-month period of winter circulation and a similar period of summer stagnation. The CSTR flow model is assumed for the entire lake during the winter circulation and for the epilimnion during the summer stagnation. Inputs of water and phosphorus from the land are assumed constant with time. For the case where $\bar{t}_{\mathrm{P}_{\mathrm{T}}}=\bar{t}_{\mathrm{H}_{2} \mathrm{O}}$, the concentration of phosphorus in the lake is time invarient throughout the year, and is equal to the average concentration in the lake inflow (Fig. 5).

When $\bar{t}_{\mathrm{P}_{\mathrm{T}}}$ is less than $\bar{t}_{\mathrm{H}_{2} \mathrm{O}}$, the average concentration of phosphorus in the lake $\left(\left[\mathrm{P}_{\mathbf{T}}\right]_{\text {lake }}\right)$ will be less than the average concentration in the lake inflow ( $\left.\left[\mathrm{P}_{\mathbf{T}}\right]_{\text {inflow }}\right)$ (Fig. 5). This occurs for example, in the Mediterranean Sea. In lakes the rapid sedimentation of inflowing phosphorus will produce similar effects. Let us assume that deposition of phosphorus in the sediments occurs in the summer stagnation but that no sedimentation occurs in winter so that phosphorus is conservative during that period. Under these circumstances, $\left[\mathrm{P}_{\mathrm{T}}\right]_{\text {1ake }}$ will increase during the circulation period, since the concentration of total phosphorus at the start of this period will be less than the steady-state value for conservative behavior. During the summer stagnation, $\left[\mathrm{P}_{\mathrm{T}}\right]$ in the epilimnion decreases with time due to settling of phosphorus from the epilimnion to the hypolimnion. Here the rate of settling of particulate phosphorus from the epilimnion must exceed the rate at which phosphate ions are added to the ion by diffusion from the hypolimnion. The $\left[\mathbf{P}_{\mathbf{T}}\right]$ in the hypolimnion may also epilimn decrease with time if the removal of phosphorus by deposition at the bottom and by diffusion to the epilimnion exceeds the rate of input of particulate phosphorus from the epilimnion.

When $\bar{t}_{\mathrm{P}}$ is greater than $\bar{t}_{\mathrm{H}_{2} \mathrm{O}}$, the average value of $\left[\mathrm{P}_{\mathrm{T}}\right]_{\text {lake }}$ will be greater than that in the lake inflow. For all cases, we can write

$$
\frac{\left[\mathrm{P}_{\mathrm{T}}\right]_{\text {lake }}}{\left[\mathrm{P}_{\mathrm{T}}\right]_{\text {inflow }}}=\frac{\bar{t}_{\mathrm{P}_{\mathrm{T}}}}{\bar{t}_{\mathrm{H}_{2} \mathrm{O}}}=\mathrm{g} .
$$

Thus, reactions which cause phosphorus to be retained in the lake system twice as long as water will lead to a doubling in the average concentration of phosphorus in the lake $\left(\left[\mathrm{P}_{\mathbf{T}}\right]_{1 \mathrm{kke}}\right)$ when compared to the lake inflow $\left(\left[\mathrm{P}_{\mathbf{T}}\right]_{\text {inflow }}\right)$. Assume that transport of soluble phosphorus from the hypolimnion to the epilimnion occurs by diffusion during the summer stagnation; such transport cannot occur during the winter circulation period. During the summer stagnation, $\left[\mathrm{P}_{\mathrm{T}}\right]$ increases with time in the epilimnion and decreases with time in the hypolimnion due to the upward diffusive transport of phosphate ions. This upward transport must exceed the rate at which phosphorus settles from the epilimnion to the hypolimnion. It is also useful to note (Fig. 5) that the return of phosphorus to the hypolimnion from the sediments during the summer can greatly accelerate the critical diffusive transport of phosphate to the euphotic zone (epilimnion) by increasing the vertical phosphate gradient. It has been observed (e.g., BuRns and Ross [2]) that this return from the sediments is accelerated by the development of anaerobic conditions in the hypolimnion. Conservative behavior of total phosphorus is resumed during the circulation period, and $\left[\mathrm{P}_{\mathbf{T}}\right]$ decreases with time towards the steady-state value for a conservative substance (Fig. 5). 
The cases presented in Fig. 5 are certainly oversimplified. However, the phenomena which they represent (circulation, stagnation, diffusion, sedimentation) occur in most lakes. These qualitative models are useful for didactic purposes, and also permit some aseful conclusions:

1. Sedimentation of a material (e.g., phosphorus) can significantly affect water quality in a lake. Rapid sedimentation can result in a lowering of the concentration of phosphorus in the euphotic zone to the extent that $\bar{t}_{\mathrm{P}_{\mathrm{T}}}$ may be less than $\bar{t}_{\mathrm{H}_{2} \mathrm{O}}$. This may occur in the Bodensee (Lake Constance) where much of the phosphorus inputs are in the form of apatites, and in Lake Erie where clays can adsorb soluble phosphate and transport it to the sediments. It is plausible that particulate organic phosphorus (e.g, algae) settles more slowly and is less effective in removing phosphorus from the lake system than particulate inorganic phosphorus. In other words $\sigma$ may vary from lake to lake. A useful lake model should provide for characterization of this settling effect (e.g., VOLLENWEIDER [22]).

2. Upward transport of soluble phosphorus to the epilimnion can produce high concentrations of phosphorus in the euphotic zone $\left(\bar{t}_{\mathrm{P}_{\mathrm{T}}}>\bar{t}_{\mathrm{H}_{2} \mathrm{O}}\right)$ and accelerate eutrophic behavior. A useful model for lakes must include this effect, together with a consideration of the return of $\mathrm{P}$ from the sediments. Such an approach could involve the use of vertical mixing coefficients $\left(k_{z}\right)$; this is discussed later in this paper.

3. Useful information about processes in lakes may be obtained by measuring the temporal and spacial changes of critical substances (e.g., P) in the lake. Note the different types of variation of $P$ with time and with lake depth which are suggested in Fig. 5, and which depend upon the relative influence of sedimentation and diffusion.

4. The physical characteristics of lakes and reservoirs can be altered. Reservoir discharges can be taken from the hypolimnion; mixing can be provided to prevent or reduce stratification; thermal discharges from power generating facilities might even be used. These physical changes will usually cause phosphorus to act more conservatively in a lake. From Fig. 5 it can be seen that this may either increase or decrease $\left[\mathrm{P}_{T}\right]$ in the epilimnion. If the nonconservative behavior of phosphorus leads

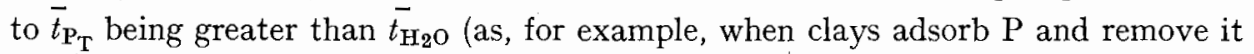
from the lake), then mixing could increase $\left[\mathrm{P}_{\mathrm{T}}\right]$ in the epilimnion by including conservative behavior.

5. Significant changes in $\left[\mathrm{P}_{\mathrm{T}}\right]$ can occur with time, even under conditions of constant hydraulic and phosphorus inputs from the land. Stated another way, accumulation or reduction of $P_{T}$ in a lake over periods of several months cannot be taken as sufficient evidence that the inputs of phosphorus to the lake from the land are increasing or decreasing a similar manner.

6. Phosphorus may appear to be 'conservative' if it is not limiting. Under these conditions altering the physical characteristics of the lake would not affect $\left[\mathrm{P}_{\mathbf{T}}\right]_{\text {lake }}$.

\section{Development of a mathematical model}

Consider a stratified lake. Assume that the epilimnion is well mixed so that a CSTR flow model may be used. By formulating a mass balance for total phosphorus in the epilimnion, the following equation is obtained: 


$$
V_{e} \frac{d\left[\mathrm{P}_{t}\right]_{e}}{d t}=W-Q\left[\mathrm{P}_{t}\right]_{e}+k_{z} A_{e} \frac{d\left[\mathrm{PO}_{a}-\mathrm{P}\right]}{d z}-\sigma V_{e}[\mathrm{PP}]_{e}
$$

Here $W$ again is the rate of input of phosphorus from the land (g/year), all of which is assumed to enter the epilimnion, $Q\left[\mathrm{P}_{\mathbf{T}}\right]_{e}$ is the rate of removal of phosphorus in the lake discharge, all of which is assumed to be taken from the epilimnion, and $\sigma V_{e}[\mathrm{PP}]_{e}$ is the rate of sedimentation of particulate phosphorus to the hypolimnion. This latter first order reaction is similar to that used by VOLLENWEIDER [22]. In this case $\sigma$ is a sedimentation coefficient (years ${ }^{-1}$ ), $V_{e}$ is the volume of the epilimnion (liters), and $[\mathrm{PP}]_{e}$ is the concentration of particulate phosphorus $(\mathrm{g} / \mathrm{l})$ in the epilimnion. The term $k_{z} A_{e} d\left[\mathrm{PO}_{4}-\mathrm{P}\right] / d z$ describes the input of phosphate to the epilimnion by diffusion from the hypolimnion; $k_{z}$ is a vertical mixing coefficient ( $\mathrm{m}^{2} /$ year or equivalent), $A_{\epsilon}$ is the horizontal area of the lake (more precisely, of the thermocline) and $d\left[\mathrm{PO}_{4}-\mathrm{P}\right] / d z$ is the gradient of phosphate across the thermocline. This assumes that the vertical transport of phosphate into the epilimnion is limited by the rate of transport of phosphate across the thermocline. The term $V_{e} d\left[\mathrm{P}_{\mathrm{T}}\right]_{e} / d t$ describes the rate of accumulation of total phosphorus on the epilimnion; $\left[\mathrm{P}_{\mathrm{T}}\right]$ e is the concentration of total phosphorus in this region and $t$ is the time.

Direct solution of equation (8) is not possible at this time because of its form ( $\left[\mathrm{P}_{\mathbf{T}}\right]_{e},[\mathrm{PP}]_{e}$ and $d\left[\mathrm{PO}_{\mathbf{4}}-\mathrm{P}\right] / d z$ are interrelated, and all depend upon time). Some assistance might be obtained by formulating a similar mass balance of $P_{\mathbf{T}}$ in the hypolimnion, but at the present time this has not proved to be sufficiently useful to permit either analytical or numerical solutions of equation (8). It seems plausible that additional attention to the mathematics, to physical, chemical and biological phenomena, and/or to simplifying assumptions may overcome present difficulties.

It is possible to make some interesting statements about phosphorus in lakes with the aid of the model represented by equation (8), as follows:

1. The vertical flux of phosphate to the epilimnion can exceed inputs of phosphorus from land runoff during the summer stagnation. For example, if $k_{z}=0.05 \mathrm{~cm}^{2} / \mathrm{sec}$ in a thermocline which is $5 \mathrm{~m}$ thick and if a gradient of $20 \mu \mathrm{g} / \mathrm{l}$ of inorganic phosphorus exists across this thermocline, the vertical flux is estimated as follows:

$$
\begin{gathered}
\text { Flux }=0.05 \mathrm{~cm}^{2} / \mathrm{sec} 20 \times 10^{-6} \mathrm{~g} / 11 / 5 \mathrm{~m} 10^{3} 1 / \mathrm{m}^{3} \mathrm{~m}^{2} / 10^{4} \mathrm{~cm}^{2} 3.16 \times 10^{7} \text { sec/year } \simeq \\
0.6 \mathrm{~g} \mathrm{P} / \mathrm{m}^{2} \text { per year }
\end{gathered}
$$

This is equal to the estimated phosphorus loading from the land to the. Vierwaldstättersee, and is also similar to the areal loadings proposed by Vollenweider (see Table 1 ) as marking the lower limit of eutrophic lakes. Since it seems probable that $k_{z}$ may be larger than $0.05 \mathrm{~cm}^{2} / \mathrm{sec}$ in the thermocline of many lakes and that a gradient of $20 \mu \mathrm{g} / \mathrm{l}$ in $5 \mathrm{~m}$ may also be exceeded in some cases, higher vertical fluxes of inorganic phosphate may be expected. The example used here is loosely based on the Vierwaldstättersee where aerobic conditions are maintained through time and depth. Hence, additional inputs of phosphorus to the hypolimnion from the sediment are not considered.

2. Considering a steady state $\left(V_{e} d\left[\mathrm{P}_{\mathrm{T}}\right] e / d t=0\right)$ and assuming that inputs from the land $(W)$ equal outputs in the lake discharge $\left(Q\left[\mathrm{P}_{\mathrm{T}}\right]_{e}\right)$, one can write that 


$$
k_{z} \frac{A_{e} d\left[\mathrm{PO}_{4}-\mathrm{P}\right]}{d z}=\sigma V_{e}[\mathrm{PP}]_{e} .
$$

Let us assume further that $\sigma=0.02 /$ day for algae based on observations by Gächter in the Horwer Bucht of the Vierwaldstättersee, that all of the phosphorus in the epilimnion is incorporated into algal cells $\left([\mathrm{PP}]_{e}=\left[\mathrm{P}_{\mathrm{T}}\right]_{e}\right)$, that the epilimnion is $15 \mathrm{~m}$ thick $\left(z_{e}=V_{e} / A_{e}=15 \mathrm{~m}\right)$ and the thermocline is $5 \mathrm{~m}$ thick $\left(z_{t}=5 \mathrm{~m}\right)$, and that all of the phosphate in the hypolimnion is present as phosphate $\left(d\left[\mathrm{PO}_{4}-\mathrm{P}\right]=\left[\mathrm{PO}_{4}-\mathrm{P}\right]_{h}=\right.$ $\left.\left[\mathrm{P}_{\mathbf{T}}\right]_{h}\right)$. Inserting these assumptions into equation (9) one obtains

$$
\frac{\left[\mathrm{P}_{\mathrm{T}}\right] e}{\left[\mathrm{P}_{\mathbf{T}}\right] h}=\frac{k_{z}}{\sigma z_{e} z_{t}}=\frac{0.05 \mathrm{~cm}^{2} / \mathrm{sec}}{0.02 / \text { day }(15 \mathrm{~m})(5 \mathrm{~m})} \frac{\mathrm{m}^{2}}{10^{4} \mathrm{~cm}^{2}}-\frac{8.64 \times 10^{4} \mathrm{sec}}{\text { day }} \simeq 0.3 .
$$

This value is not unreasonable and, given the approximate nature of the assumptions made, suggests that the general approach used in equation (8) and the values of the coefficient $k_{z}$ and $\sigma$ are plausible.

3. Consider the ratio $\left[\mathrm{P}_{\mathrm{T}}\right]_{e} /\left[\mathrm{P}_{\mathrm{T}}\right]_{h}$, and the schematic curves presented in Fig. 5. When ${\overline{\mathrm{t}_{\mathrm{T}}}}_{\mathrm{t}_{\mathrm{t}}} / \bar{t}_{\mathrm{H}_{2} \mathrm{O}}$ is less than one, it appears that $\left[\mathrm{P}_{\mathrm{T}}\right] e /\left[\mathrm{P}_{\mathrm{T}}\right]_{h}$ should be less than one. Similarly, when $\vec{t}_{\mathrm{P}_{\mathrm{T}}} / \bar{t}_{\mathrm{H}_{2} \mathrm{O}}>1,\left[\mathrm{P}_{\mathrm{T}}\right]_{e} /\left[\mathrm{P}_{\mathrm{T}}\right]_{h}$ is $>1$, and when $\vec{t}_{\mathrm{P}_{\mathrm{T}}} \bar{t}_{\mathrm{H}_{2} \mathrm{O}}=1$, then $\left.\left[\mathrm{P}_{\mathrm{T}}\right]_{e}\right]$ $\left[\mathrm{P}_{\mathbf{T}}\right]_{h}=1$. This is consistent with equation (10), which suggests that $\left[\mathrm{P}_{\mathrm{T}}\right]_{e} /\left[\mathrm{P}_{\mathrm{T}}\right] h$ and therefore ${\overline{\mathrm{P}_{\mathrm{T}}}}_{\mathrm{T}} / \bar{t}_{\mathrm{H} 2 \mathrm{O}}$ are functions of the ratio $\left(k_{z} / \sigma\right)$. Slow settling (small $\sigma$ ) and rapid vertical mixing (large $\left.k_{z}\right)$ will lead to accumulation of phosphorus in the lake $\left(\bar{t}_{\mathrm{P}_{\mathrm{T}}}\right)$ $\bar{t}_{\mathrm{H}_{2} \mathrm{O}}>1$ ), while rapid settling (large $\sigma$ ) and slow vertical mixing (small $k_{z}$ ) lead to a removal of phosphorus from the lake $\left({\overline{\mathrm{t}_{\mathrm{T}}}}_{\mathrm{T}} / \overline{\mathrm{t}}_{\mathrm{H}_{2} \mathrm{O}}<1\right)$. This analysis neglects the possible return of phosphorus from the sediments to the hypolimnion under anaerobic conditions.

4. The upward diffusive flux, in addition to depending upon vertical mixing, will also depend upon the concentration of inorganic phosphorus in the hypolimnion $\left(\left[\mathrm{PO}_{4}-\mathrm{P}\right]_{h}\right)$. This in turn will depend upon the depth of the lake. Algal cells which are produced in the epilimnion comprise one form of particulate phosphorus and will settle into the hypolimnion where they are energy source for heterotrophic organisms. This heterotrophic activity releases phosphorus into the hypolimnion. While the amount of phosphorus released will depend upon the amount of algae which is mineralized, the actual concentration of phosphate which is produced will depend upon the volume of the hypolimnion. In other words, large (deep) lakes will develop lower concentrations of phosphate in the hypolimnion than will shallow lakes receiving the same phosphorus inputs in land runoff. This in turn will result in a smaller phosphate gradient $\left(d\left[\mathrm{PO}_{4}-\right.\right.$ $\mathrm{PJ} / d z$ ) and a smaller diffusion flux of phosphorus to the epilimnion. As a result, deep lakes can assimilate higher phosphorus loadings than shallow lakes before becoming eutrophic (RAWSON [14], VOLLENWEIDER [21]). It is plausible that a mathematical relationship describing this effect can be developed using equation (8) as a basis.

\section{The Vierwaldstättersee and the Horwer Bucht}

Three points will be considered here: 1 . the increase in $\left[\mathrm{P}_{\mathrm{T}}\right]$ with time and distance

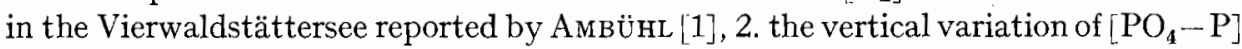
and $\left[\mathrm{P}_{\mathrm{T}}\right]$ in the Vierwaldstättersee (AMBÜHL $[1]$ ) and in the Horwer Bucht (GäCHTER 


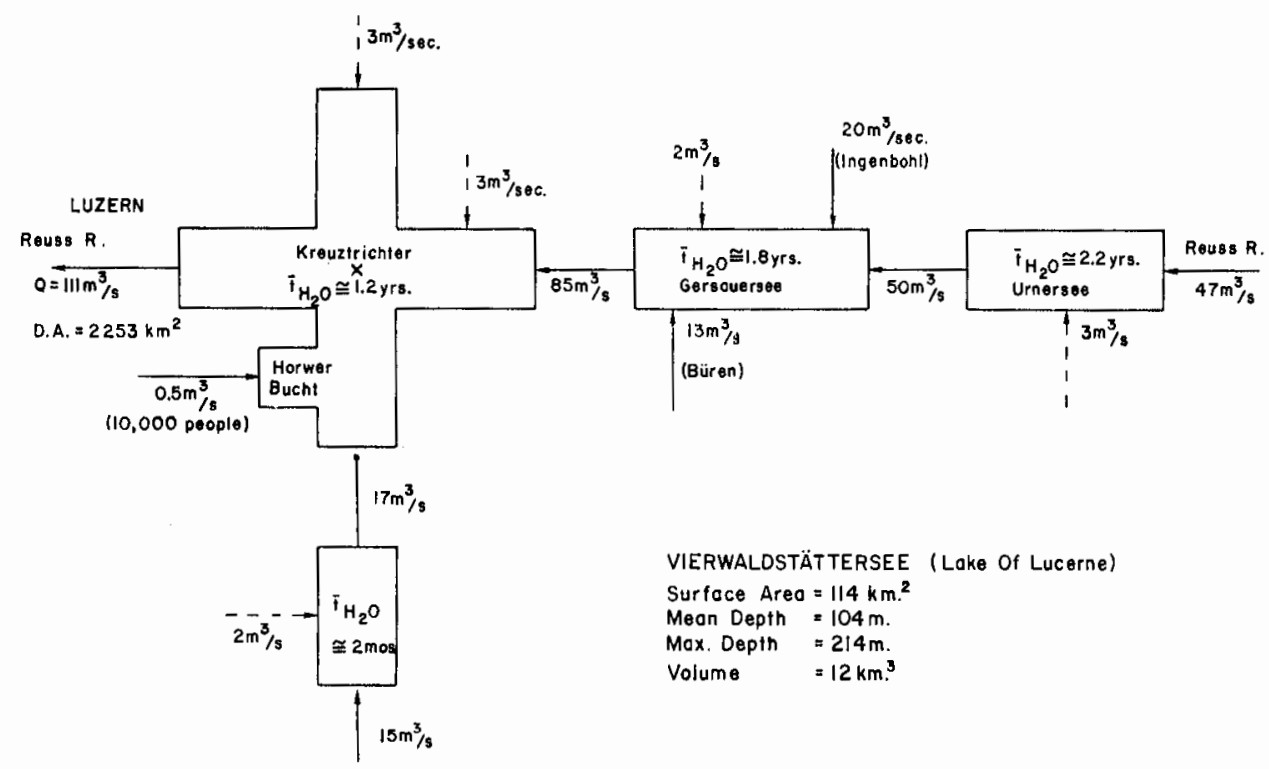

Fig. 6. Hydrology of the Vierwaldstättcrsee.

[4], personal communication) and 3. the horizontal variation of $\left[\mathrm{P}_{\mathrm{T}}\right]$ in the Horwer Bucht reported by GÄchTER et al. [4]. Let us begin by considering the hydraulics of the Vierwaldstättersee (Fig, 6).

The average discharge from the Vierwaldstättersee in the Reuss River at Lucerne is $111 \mathrm{~m}^{3} / \mathrm{sec}$. A total of $95 \mathrm{~m}^{3} / \mathrm{sec}$ enters the lake through Seedorf, Büren, Ingenbohl and Sarnen, so that $(95 / 111)$ or about $85 \%$ of the discharge is introduced to the lake at four point sources. Water entering the system in the Reuss River through Seedorf would remain in the lake an average of $(2.2+1.8+1.2)$ or 5.2 years (Fig. 6$)$. The lake areas denoted as Urnersee, Gersauersee and Kreuztrichter might be profitably modeled with the 'lakes in series' approach used by O'Connor and Mueller [11]. Untreated wastewater and surface water from the Horw area enter the lake at the Horwer Bucht. This flow (approximately $0.5 \mathrm{~m}^{3} / \mathrm{sec}$ ) includes the waste from approximately 10,000 people and has an average residence time in the lake of about 1.2 years. These residence times are calculated using the total volume of the segment of the lake under consideration and estimates of the average flows introduced into the lake segment. Flow estimates are extrapolated from available records (Hydrographisches Jahrbuch der Schweiz). Measurements of the chemical quality of the inflows and the lake outflow are not available.

AмвӥHL [1] has reported that the concentration of total phosphorus in the Vierwaldstättersee increases along the Urnersee to Gersauersee to Kreuztrichter series (Fig. 7) and increases with time in each of these lake segments. One explanation for these effects includes a) the possible continuous increase in the rate of input of phosphorus to each lake segment throughout the 5-year period of observation, thereby resulting in an increase in $\left[\mathrm{P}_{\mathbf{T}}\right]$ with time in each lake segment, and $\mathrm{b}$ ) increasing 


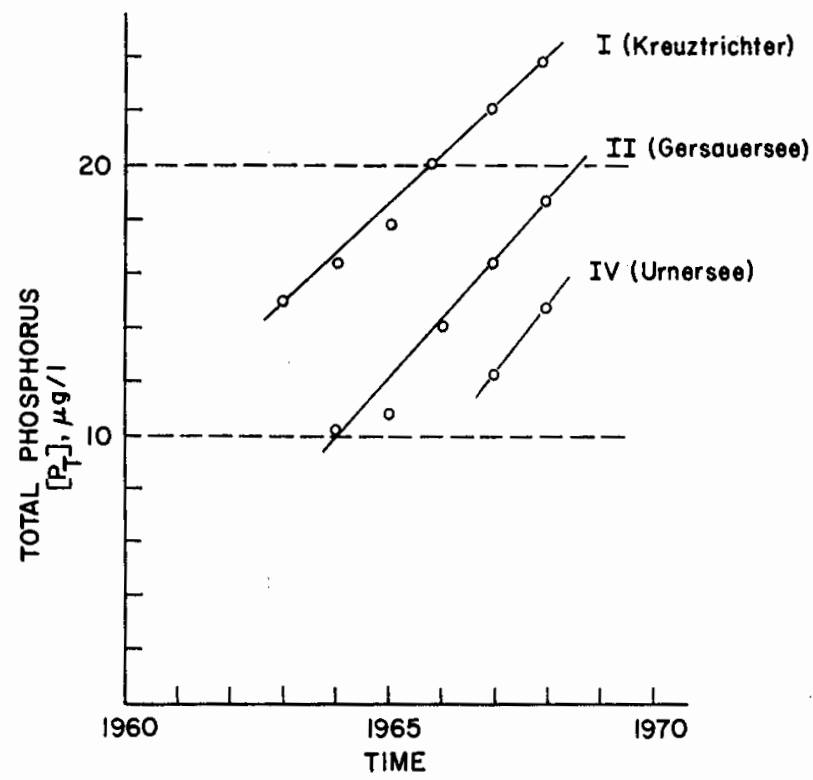

Fig. 7. Total phosphorus in three segments of the Vierwaldstättersee as a function of time (after AMB ÜHL [1]).

inputs at any given time along the series Urnersee-Gersauersee-Kreuztrichter (in other words, $\left[\mathbf{P}_{\mathbf{T}}\right]_{\text {inflow }}($ Urnersee $)<\left[\mathbf{P}_{\mathbf{T}}\right]_{\text {inflow }}($ Gersauersee $)<\left[\mathbf{P}_{\mathbf{T}}\right]_{\text {inflow }}($ Kreuztrichter)). While these explanations may be correct, another plausible situation is outlined in the following paragraphs.

Consider an entire lake as a CSTR. This application of the Vollenweider-O'Connor and Mueller approach may be useful over several mixing intervals (several years). Let the input of phosphorus to the lake change sharply at some time $(t=0)$ so that the new input is some multiple $(f)$ of the original input $\left(\left[\mathrm{P}_{\mathbf{T}}\right]_{\text {inflow }}, t>0=f\left[\mathbf{P}_{\mathbf{T}}\right]_{\text {inflow }}\right.$, $t<0$ ). This change is termed a step-signal input. The response to this input change by the lake contents and the lake outflow may then be described as follows, if $\bar{t}_{\mathrm{P}_{\mathrm{T}}}=\bar{t}_{\mathrm{H}_{2} \mathrm{O}}$ and the lake is at a steady state before the change:

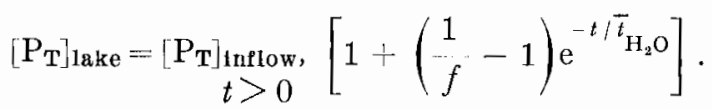

If $\bar{t}_{\mathrm{P}_{\mathrm{T}}}=\mathrm{g} \bar{t}_{\mathrm{H}_{2} \mathrm{O}}$ (equation (7)) then the steady state value of $\left[\mathrm{P}_{\mathrm{T}}\right]_{\text {lake }}$ is equal to $\left.\mathrm{g}\left[\mathrm{P}_{\mathbf{T}}\right]\right]_{\text {infiow }}$. It is also plausible that

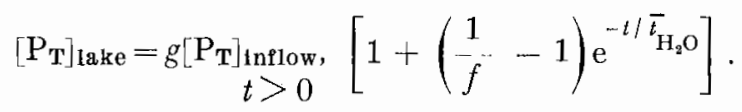

Equation (12) is presented in graphical form in Fig. 8 for an instantaneous doubling of the phosphorus inputs $(f=2)$ to a lake with a hydraulic detention time of 2 years, and for both conservative $(g=1)$ and nonconservative $(g=0.5$ and 2) behavior. For all cases, the concentration of total phosphorus in the lake increases with time even though 


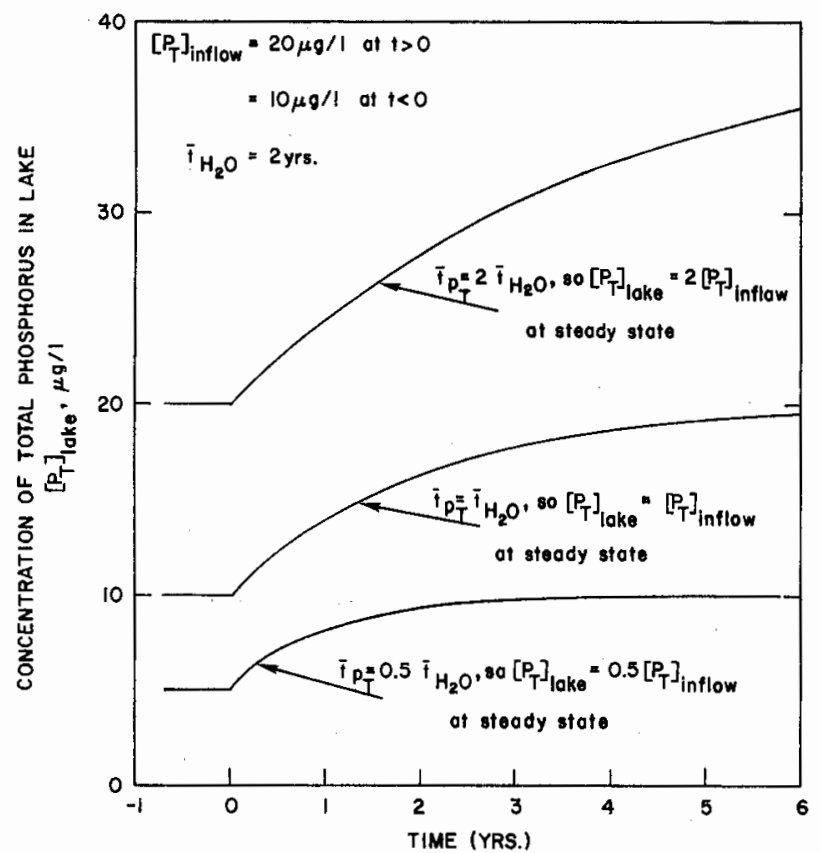

Fig. 8. Response of a lake to an instantaneous doubling of the phosphorus input to the lake at $t=0$, for conservative and nonconservative behavior.

the phosphorus input is constant at $t>0$. While most lakes will not experience 'step-signal' clianges in phosphorus inputs, these results illustrate the lag effects which can result from any change in lake inputs. Stated another way, changes in lake contents cannot be ascribed to simultaneous changes in lake inputs. Furthermore, step-signal changes in lake inputs may occur in some lakes as, for example, the possible addition of waste from Chicago to Lake Michigan, the results to be achieved from waste treatment for phosphorus removal, the effects of a ban on phosphorus in detergents, and the consequences of a diversion of waste from the Horwer Bucht to the Reuss River downstream from Lucerne. As noted earlier in Fig. 5, $\left[\mathrm{P}_{\mathrm{T}}\right]_{\text {lake }}$ at a steady state increases with $g$. It is also significant to note that the response of lakes with $g<1$ (sedimentation greater than recycling) is faster than for lakes within which phosphorus is conservative $(g=1)$. Similarly, when recycling effects exceed sedimentation effects $(g>1)$, then longer periods are required for a new steady state to be reached. These results provide an additional perspective for the changes is $\left[\mathrm{P}_{\mathrm{T}}\right]_{\text {lake }}$ with time noted by АмвÜHL [1]. Note here, however, that equation (12) has not been derived, but has been proposed on the basis of equation (11).

Phosphorus removed by sedimentation in the Urnersee will not be introduced to the Gersauersee. Similarly, phosphorus removed by sedimentation in either of these two lake segments will not reach the Kreuztrichter. On this basis one might expect a decrease in $\left[\mathrm{P}_{\mathbf{T}}\right]_{\text {lake }}$ at any given time along the Urnersee-Gersauersee-Kreuztrichter series. As noted earlier, just the opposite trend as reported by AмBÜHL [1]. It is proposed here that these observed results may be due in large part to differences in 


\section{CONCENTRATION OF PHOSPHORUS $(\mu g P / I)$}

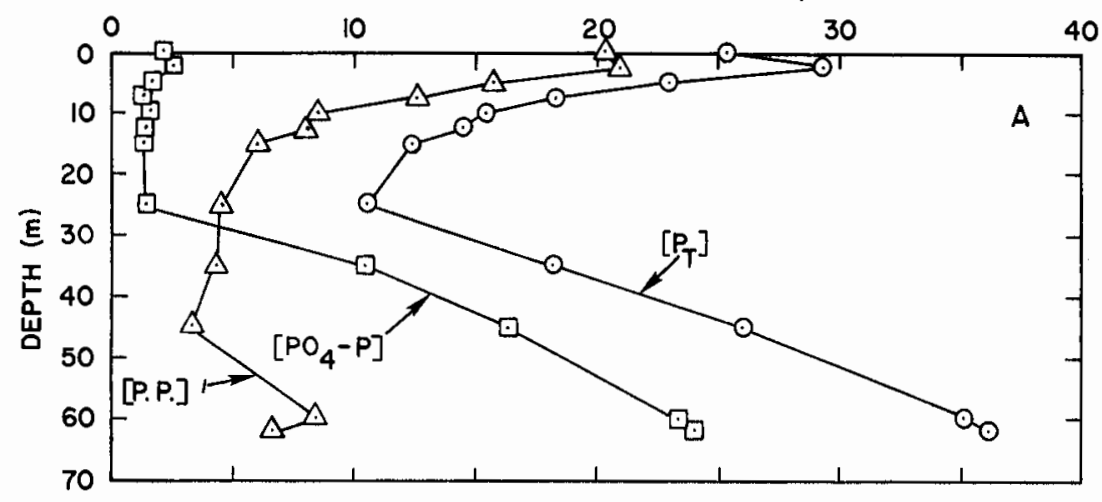

APPARENT OXYGEN UTILIZATION (AOU)

DISSOLVED OXYGEN (mg/l)

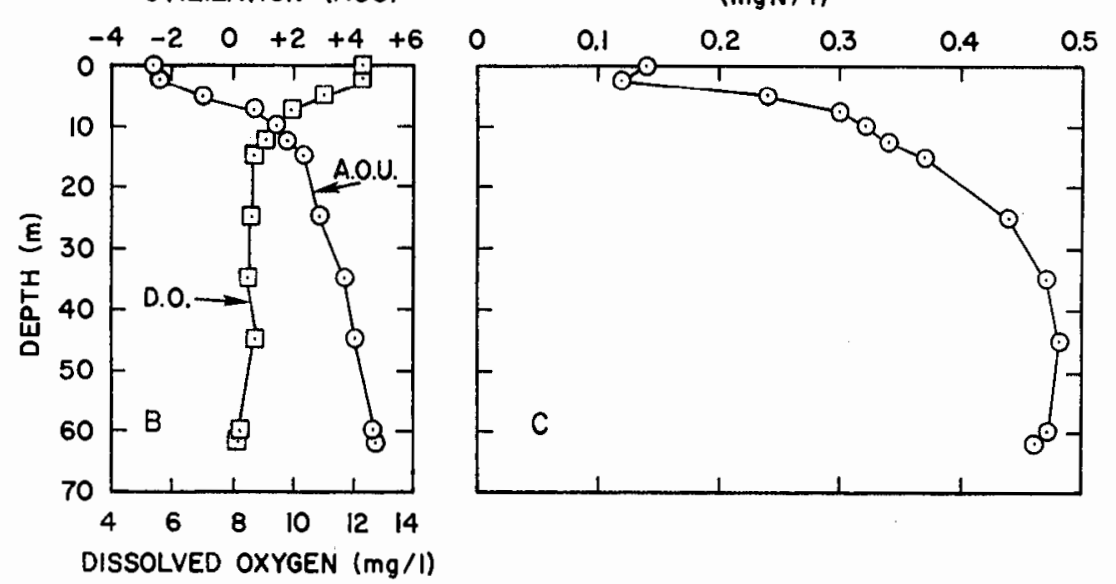

CONCENTRATION OF NITRATE ( $\mathrm{mgN} / \mathrm{l})$

Fig. 9. Phosphorus, nitrate, dissolved oxygen, and apparent oxygen utilization versus depth. Data obtained in Horwer Bucht, 14 September 1970 by Gächter.

vertical transport of phosphate resulting from differences in the sizes of the hypolimnia of these lake segments. Rough estimates of mean lake depths are as follows: Urnersee $170 \mathrm{~m}$, Gersauersee $150 \mathrm{~m}$ and Kreuztrichter $60 \mathrm{~m}$. The Gersauersee is actually comprised of a smaller western pocket with surface area about $6 \mathrm{~km}^{2}$ and a mean depth of $80 \mathrm{~m}$ together with a larger eastern portion with a surface area of about $25 \mathrm{~km}^{2}$ and a mean depth of about $190 \mathrm{~m}$. Average concentrations of total phosphorus in the three lake segments for 1968 are $15 \mu \mathrm{g} / \mathrm{l}, 19 \mu \mathrm{g} / \mathrm{l}$, and $24 \mu \mathrm{g} / \mathrm{l}$ for the Urnersee, Gersauersee and Kreuztrichter, respectively, in the same order as their average depths. These results could be accomplished by recycling of phosphorus from the euphotic zone to the deeper waters and back again. Algae produced in the euphotic zone will settle to the deeper waters where they are mineralized. The concentration of inorganic phosphate which is produced in the deeper waters is inversely related to their volume. Deep lakes (e.g., the Urnersee) will produce smaller concentrations of $\mathrm{PO}_{4}-\mathrm{P}$, resulting in 
lower vertical phosphate gradients and smaller return fluxes of phosphorus to the euphotic zone. The relatively high concentration of $\mathrm{PO}_{4}-\mathrm{P}$ in the Gersauersee relative to the Urnersee could be due to high recycling rates in its shallow western pocket. Phosphorus recycled to the surface layers by diffusion in the western pocket could be dispersed horizontally to some extent by mixing in the epilimnion. This interpretation requires that the concentration of $\mathrm{PO}_{4}-\mathrm{P}$ in the hypolimnion of the western pocket be significantly higher than that in the main portion of the Gersauersee. Data are not available at present to test this hypothesis.

Let us consider next the vertical distribution of phosphate species reported by Амв ̈̈нL [1] and GäcHTER [4] (personal communication). Experimental data obtained by Gächter for the Horwer Bucht during summer stagnation are presented in Fig. 9A, $\mathrm{B}$ and $\mathrm{C}$. A pronounced minimum in total phosphorus occurs at a depth of about $25 \mathrm{~m}$. In the upper 10 to 15 meters, phosphorus is predominantly in particulate form (presumably algae) while $\mathrm{PO}_{4}-\mathrm{P}$ is present in small concentrations (generally $0-2 \mu \mathrm{g} / \mathrm{l})$ during the stagnation period. Below 25 meters, the concentration of particulate phosphorus is relatively small, while $\left[\mathrm{PO}_{4}-\mathrm{P}\right]$ increases in an approximate linear manner with depth (Fig. 9A). Profiles for other substances $\left(\mathrm{NO}_{3}-\mathrm{N}\right.$, Fig. 9 C, D.O., Fig. 9 B, $\mathrm{H}_{2} \mathrm{CO}_{3}{ }^{*}$, Fig. $2 \mathrm{C}$ ) and for the Apparent Oxygen Utilization (AOU, Fig. 9B) do not show similar trends.

The high concentration of total phosphorus in the epilimnion could be due to increased inputs of phosphorus in surface runoff $\left(\left[\mathrm{P}_{\mathrm{T}}\right]_{\text {inflow }}\right)$ during the summer months; the high concentration of $\mathrm{PO}_{4}-\mathrm{P}$ in the bottom of the hypolimnion could be due to decomposition of particulate organic phosphorus in the sediments. This latter explanation is not consistent with the oxygen (Fig. 9B) and nitrate (Fig. 9C) profiles. It is also unlikely that $\left[\mathrm{P}_{\mathrm{T}}\right]_{\text {inflow }}$ increases significantly during the summer. An alternative explanation lies in the sedimentation-recirculation patterns discussed throughout this paper. Algae produced in the euphotic zone will liberate nitrogen and phosphate and consume oxygen in the hypolimnion when they serve as an energy source for heterotrophic organisms. The more or less uniform concentration of dissolved oxygen and nitrate in the hypolimnion (Fig. 9B and C) suggest that this heterotropic breakdown of particulate organic materials is distributed throughout the hypolimnion. A significant vertical gradient of $\mathrm{PO}_{4}-\mathrm{P}$ in the deeper waters could result if vertical diffusion in the upper portions of the hypolimnion and the thermocline were sufficient to transport phosphate upward to the euphotic zone as fast as it enters in to or is produced within this region (from 10 to 25 meters in depth). Nitrate would not be transported upwards as rapidly because it is not limiting in the upper water, with relatively high concentrations of $\mathrm{NO}_{3}-\mathrm{N}$ present in the epilimnion. The nitrate input from the land due to agricultural use is estimated as follows (after VOLLENWEIDER [21]:)

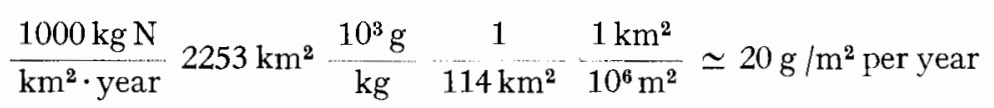

Vertical transport is approximated (equation (4)) as follows:

$$
\frac{0.05 \mathrm{~cm}^{2}}{\mathrm{sec}} \frac{0.1 \times 10^{-3} \mathrm{~g}}{1} \frac{1}{5 \mathrm{~m}} \cdot \frac{10^{3} \mathrm{l}}{\mathrm{m}^{3}} \frac{\mathrm{m}^{2}}{10^{4} \mathrm{~cm}^{2}} \frac{3.15 \times 10^{7} \mathrm{sec}}{\text { year }} \simeq 3.2 \mathrm{~g} / \mathrm{m}^{2} \cdot \text { year }
$$




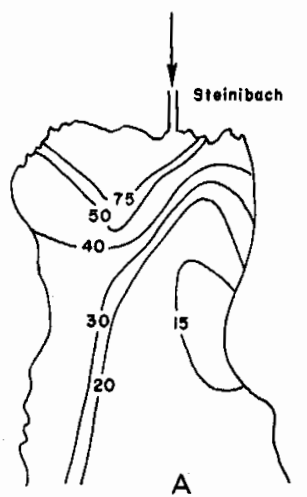

A

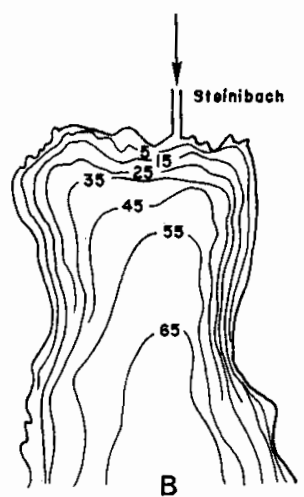

B

\section{$N$}

Fig. 10. Lake depth (meters, Fig. $10 \mathrm{~B}$ ) and total phosphorus in the surface waters $(\mu \mathrm{g} / \mathrm{l}$, Fig. $10 \mathrm{~A}$ ) for the Horwer Bucht. Fig. 10A from GäChTER et al. [4].

This assumes a nitrate gradient of $0.1 \mathrm{mg} \mathrm{N} / 1$ across a $5 \mathrm{~m}$ depth and a vertical mixing coefficient of $0.05 \mathrm{~cm}^{2} / \mathrm{sec}$. Land inputs $\left(20 \mathrm{~g} / \mathrm{m}^{2}\right.$ per year) are significantly greater than diffusive inputs $\left(3 \mathrm{~g} / \mathrm{m}^{2}\right.$ per year). It is plausible, then, that the vertical distribution of $\mathrm{PO}_{4}-\mathrm{P}$ and the minimum in $\left[\mathrm{P}_{\mathrm{T}}\right]$ at a depth of $25 \mathrm{~m}$ are associated with the nutrient-limiting characteristic of $P$ in the lake and the vertical circulation patterns in the hypolimnion of the lake. Studies to determine $k_{z}$ from temperature data using the techniques of LERMON and STILLER [6] could be useful in testing this hypothesis.

Pronounced horizontal variation of the concentration of total phosphorus in the surface waters of the Horwer Bucht has been reported by GÄCHTER et al. [4] (Fig. 10 A). Phosphorus originating primarily in domestic waste enters the Horwer Bucht at the north end. Phosphorus concentrations in the surface water are highest at the north end and along the western shore of the bay (Fig. 10A). Possible explanations for this distribution include 1. accumulation along the western shore of phosphorus introduced at the north end in the municipal waste, due to wind-induced or hydraulic currents in the surface waters, 2 . introduction of phosphorus from the land along the western shore, including possible runoff from Hergiswil and 3. enhanced recirculation of phosphorus from the hypolimnion to the epilimnion by diffusion, due to the relatively shallow hypolimnion along the western shore (Fig. 10B). Presently available data do not permit a firm conclusion concerning the relative significance of these three mechanisms. Attention here is directed toward establishing the plausibility of the third source, i.e., enhanced vertical transport of phosphorus along the western shore due to the relatively shallow depth in that region.

Surface runoff into the Horwer Bucht is approximately $1 \mathrm{~m}^{3} / \mathrm{sec}$. The volume of the bay is about $7.5 \times 10^{7} \mathrm{~m}^{3}$. Hence $\bar{t}_{\mathrm{H}_{2} \mathrm{O}}$ is about 2.4 years if it is assumed (unrealistically) that no input of water occurs from the Vierwaldstättersee to the bay. Phosphorus inputs to the bay are estimated as $3 \times 10^{4} \mathrm{~g} /$ day $(10,000$ people, 3 g/capita-day) 
Assuming an average phosphorus concentration in the bay of $25 \mu \mathrm{g} / 1, \bar{t}_{\mathrm{P}_{\mathrm{T}}}$ is estimated as 0.17 year. Here again no exchange between the lake and the bay is considered.

An estimate of the exchange of water between the lake and the bay can be obtained by following the distribution of a conservative material. A one day survey was conducted; concentrations of sodium and chloride in the surface waters of the Horwer Bucht were measured, together with measurements of the inputs of flow $\left(0.133 \mathrm{~m}^{3} /\right.$ $\mathrm{sec})$, total phosphorus $(2.5 \mathrm{mg} / \mathrm{l})$, sodium $(20 \mathrm{mg} / \mathrm{l})$ and chloride $(12 \mathrm{mg} / \mathrm{l})$ from the Horw area. No horizontal variations in sodium $(2.2 \mathrm{mg} / \mathrm{l})$ or chloride $(1.2 \mathrm{mg} / \mathrm{l})$ were observed in the surface waters of the Horwer Bucht over the length and width of the bay. Concentrations of these substances were lower in the hypolimnion $\left(\left[\mathrm{Na}^{+}\right]=\right.$ $1.6 \mathrm{mg} / \mathrm{l},[\mathrm{Cl}-]=0.8 \mathrm{mg} / \mathrm{l})$. If it is assumed that the surface waters of the Vierwaldstättersee would contain 0.8 and $1.6 \mathrm{mg} / 1$ if $\mathrm{Cl}^{-}$and $\mathrm{Na}^{+}$, respectively, without the input of these ions from the Horw waste, then a flow of water from the Vierwaldstättersee to the Horwer Bucht of about $4 \mathrm{~m}^{3} / \mathrm{sec}$ is required. Considering these inputs of water ( $1 \mathrm{~m}^{3} / \mathrm{sec}$ from land, $4 \mathrm{~m}^{3} / \mathrm{sec}$ from the lake) into the epilimnion of the bay $\left(1.5 \times 10^{7} \mathrm{~m}^{3}\right), \bar{t}_{\mathrm{H}_{2} \mathrm{O}}$ is estimated as 35 days. This estimate, while considerably lower than 2.4 years, is probably still too high, since the lake water entering the bay has chloride and sodium concentrations in excess of 0.8 and $1.6 \mathrm{mg} / 1$, respectively. Assuming that phosphorus acts conservatively (which it does not), that concentrations of total phosphorus of $25 \mu \mathrm{g} / 1$ and $20 \mu \mathrm{g} / \mathrm{l}$ are in the surface waters the bay and the lake, respectively, that the phosphorus input in the Horw waste is $3 \times 10^{4} \mathrm{~g} / \mathrm{day}$, and that these inputs are to the epilimnion, then $\bar{t}_{\mathrm{H}_{2} \mathrm{O}}=\bar{t}_{\mathrm{P}_{\mathrm{T}}}=3.5$ days. It is likely that this last estimate is also not exact. Since we do not know whether $\bar{t}_{P_{\mathrm{T}}}$ is less than, equal to, or greater than $\bar{t}_{\mathrm{H}_{2} \mathrm{O}}$, let us estimate $\bar{t}_{\mathrm{H}_{2} \mathrm{O}}$ as being 5 days, within half an order of magnitude. In any event, $\bar{t}_{\mathrm{H}_{2} \mathrm{O}}$ is considerably less than 2.4 years, indicating that extensive mixing occurs between the surface waters of the lake and the bay, and suggesting that the surface waters in the bay are also rather well mixed.

It is proposed here that recirculation of phosphorus from the bottom waters to the surface waters of the Horwer Bucht occurs in sufficient quantities to affect the concentration of total phosphorus in these surface waters. It is further proposed that the upward flux of phosphorus varies in some inverse manner with the depth. The phosphorus profiles in Fig. $10 \mathrm{~A}$ would then be the result of a continuous upward input which is highest along the shallow western shore (see Fig. 10B), a continuous point source from the Horw waste, and extensive mixing with the waters of the Vierwaldstättersee. If this picture is correct, then the following should also be observed: 1 . the removal of the Horw waste from the bay in 1972 should reduce the high concentrations at the northern end of the bay, but the gradients along the western bank should persist, although at lower levels, and 2. vertical profiles of $\left[\mathrm{P}_{\mathrm{T}}\right]$ and $\left[\mathrm{PO}_{4}-\mathrm{P}\right]$ along the western shore should show higher concentrations of these parameters at the $10-25 \mathrm{~m}$ depths than similar profiles along the center of the bay during summer stagnations now and in the future.

\section{Concluding remarks}

Predictive models for lakes which can relate water quality with lake inputs and lake morphology would be useful. An approach to the development of such models is 
presented in this paper. Consideration of this approach leads to the following statements:

1. Water quality in lakes varies with distance and time. Spacial variation is predominantly vertical. Temporal variations occur seasonally due to stratification, and over periods of years due to changes in inputs. Predictive water quality models should reflect these variations. Less emphasis should be placed on average measurements within lakes; more effort should be directed toward measuring inputs and discharges and the temporal variations in these flows.

2. Recycling of materials from the deeper waters to the euphotic zone can be an important source of nutrient materials. These vertical fluxes should be included in predictive mathematical models, together with the downward flux of materials by sedimentation. Release of nutrients from the sediments might prove significant in lakes containing anaerobic hypolimnia.

3. It seems plausible that a predictive mathematical model for lakes can be developed which relates water quality with nutrient inflow and lake depth. Such a model would be analogous to the Streeter-Phelps-O'Connor model for streams and estuaries, and could prove to be as useful. Empirical measurements of mixing and sedimentation coefficients would be required.

4. The development and use of a predictive mathematical model for lakes will require the expertise from several disciplines, viz, engineering, chemistry, and biology. Potential modelers should recognize this need when beginning serious efforts in this field.

\section{ACKNOWLEDGMENT}

The writer is grateful for the advice and criticism received from W. Stumm, R. Gächter and H. Ambühl of the Swiss Federal Institute of Technology. More specifically, any merits of this paper are derived from their in puts, while the deficiencies originate with the writer. The financial support of the Swiss Federal Institute of Technology and the University of North Carolina is also gratefully acknowledged.

\section{REFERENCES}

[1] АмвӥнL, H., Die neueste Entwicklung des Vievwaldstättersees, Int. Verein. theor. angew. Limnol. 17, 219-230 (1969).

[2] Burns, N. M., and Ross, C., Nutrient Relationships in a Stratified Eutrophic Lake, paper presented at 161st ACS National Meeting (Los Angeles, April 1971).

[3] Dutton, J. A., and Bryson, R. A., Heat Flux in Lake Mendota, Limnol. Oceanogr. 7, 80 97 (1962).

[4] GÄChter, R., SzaBó, E., and Mareš, A., Die lokale Beeinflussung eines stehenden Gewaissers durch eine punktförmige Abwasserbelastung; ein divekter Nachweis der wachstumsbegrenzenden Wirkung des Phosphors im Vierwaldstättersee, Schweiz. Z. Hydrol. 33, 66-72 (1971).

[5] Hutchinson, G. E., A Treatise on Limnology, Vol. 1 (John Wiley and Sons, New York 1957).

[6] Lerman, A., and Stiller, M., Vevtical Eddy Diffusion in Lake Tibevias, Int. Verein. theor. angew. Iimnol. 17, 323-333 (1969).

17] L, , Y. I., TA Kahashi, T., and BroEcker, W. S., Degree of Saturation of CaCO $\mathrm{O}_{3}$ in the Oceans, J. geophys. Res. 74, 5507-5525 (1969).

[8] Munk, Walter H., Abyssal Recipes, Deep Sea Res, 13, 707-730 (1966).

[9] O'Connor, D. J., Oxygen Balance of an Estrayy, Trans. Am. Soc. Civ. Eng. 126, 556-576 (1961).

[10] O'Connor, D. J., and DobBins, W. E., Mechanism of Reaeration in Natural Streams, Trans. Am. Soc. Civ. Eng. 123, 641-684 (1958).

[11] O'Connor, D. J., and Mueller, J. A., Water Quality Model of Chlorides in Great Lakes, Proc. Am. Soc. Civ. Eng. San. Eng. Div., J. 96, No. SA 4, 955-975 (1970).

[12] Odum, H. T., Primary Production in Flowing Waters, Limnol. Oceanogr. 1, 102-117 (1956). 
[13] Piontelli, R., and Tonolli, V., Il Tempo di Residenza Delle Acque Lacustri in Relazioni al Fenomeni di Arrichimento in Sostanze Immesse, con Particolare Riguardo al Lago Maggiure, Mem. 1st. ital. Idrobiol. 17, 247-266 (1964).

[14] Rawson, D. S., Morphometry: as a Iominant Factor in the Productivity of Large Lakes, Int. Verein, theor. angew. Limnol. 1, 164-175 (1955).

[15] ReDFIELD, A. C., KETCHUM, B. H., and Richards, F. A., The Influence of Organisms on the Composition of Sea Watev, chapter 2, p. 26-77, in: The Sea, Vol. 2 (Ed. M. N. Hill, Interscience Publishers, New York 1962).

[16] Rulsx, Gordon A., Oxygen, Phosphate, and Nitrate in the Atlantic Ocean, Bull. Bingham oceanogr. Coll. 13, 1-126 (1951).

[17] SAWYER, Clair N., Fertilization of Lakes by Agricultural and Urban Drainage, J. New Eng1. Wat. Works Ass. 61, No. 2, 109-127 (1947).

[18] Streeter, H. W., and PHet.ps, Earle B., A Study of the Pollution and Natural Purification of the Ohio River. III. Factors Concerned in the Phenomena of Oxidation and Reaeration, Public Heaith Buli. No. 146 (U.S. Public Ffealth Service, Washington, D.C. 1925).

[19] Sтuмm, Werner, The Accelevation of the Hydrogeochemical Cycling of Phosphorus, paper presented at the Symposium of the Nobel Foundation, August 1971, Sweden, to be published in April, 1972, in: Nobel Symposia Series, (John Wiley and Sons, New York 1972).

[20] Takahashi, T., Broecker, W., Li, Y. H., and Thurber, D., Chemical and Tsolopic Balances for a Meromictic Lake, Limnol. Oceanogr. 13, 272--292 (1968).

[21] VOLLENWEIDER, R. A., Scientific Fundamentals of the Eutrophication of Lakes and Floreing Waters, with Particular Refevence to Nitrogen and Phosphorus as Factors in Eutrophication, Technical Report No. DAS/CSI/68.27 (Organization for Economic Cooperation and Development, Paris 1968).

[22] VollenweIder, R. A., Möglichkeiten und Grenzen elementarer Modelle der Stoffbilanz von Seen, Arch. Hydrobiol. 66, 1-36 (1969).

Address of the author:

Prof. Charles R. O'Melia, Department of Environmental Sciences and Engineering, University of North Carolina, Chapel Hill, N.C. 27514, USA. 